\title{
28. LOWER CRETACEOUS BENTHIC FORAMINIFER ASSEMBLAGES, EQUATORIAL ATLANTIC: BIOSTRATIGRAPHIC, PALEOENVIRONMENTAL, AND PALEOBIOGEOGRAPHIC SIGNIFICANCE ${ }^{1}$
}

\author{
Ann E.L. Holbourn² and Michel Moullade ${ }^{3}$
}

\begin{abstract}
Lower Cretaceous benthic foraminiferal assemblages from basal sedimentary sequences of Holes 959D, 962B, and 962D provide time constraints for the onset of marine sedimentation on the Côte d'Ivoire-Ghana Transform Margin and show that marine conditions were already established by late Aptian-early Albian near Hole 959D and by mid to late Albian near Hole 962D. The foraminiferal data suggest that older Aptian-Albian marine sequences were subsequently reworked into upper Albian-lowermost Cenomanian sediments within tectonically active sub-basins. Marked fluctuations in test size, abundance, and diversity reflect a pulsed sedimentation pattern with an overall high accumulation rate. Three main cycles of deposition are detected from overall changes in preservation, abundance and diversity, which are possibly related to major shifts in sediment provenance and/or supply. The composition of the benthic foraminiferal assemblages at Holes 959D and 962D indicates an outer shelf to upper bathyal setting and reflects a combination of Tethyan, South Atlantic, and local endemic faunal influences, pointing to restricted connections with the open ocean and Tethys during the late Albian and early Cenomanian. There is no evidence for bottom-water anoxia or severe dysoxia during the deposition of Cores 159-962D-16R through 37R. The high dissolution of planktonic tests and absence or scarcity of benthic foraminifers in the upper part of the sequence (Sections 159-962D-7R-1 through 13R-1 and 159962B-8H-5 through 9H-6) indicate some later deterioration in bottom-water oxygenation.
\end{abstract}

\section{INTRODUCTION}

Except for some early investigations by de Klasz et al. (1960, 1961, 1963), de Klasz and Rérat (1962, 1963), Castelain et al. (1962), Fayose and de Klasz (1976), and Petters (1982, 1983), which focused on Upper Cretaceous foraminiferal assemblages from equatorial western Africa, very few studies have been published on Lower Cretaceous foraminifers from western African basins. De Klasz and du Chêne (1978) reported Albian-Cenomanian marine sequences, onshore and offshore, from Liberia to Nigeria, but did not include any foraminiferal data in their review. In a recent study, Saint-Marc and N'Da (in press) described upper Albian-Cenomanian marine sequences containing sparse planktonic and benthic foraminifers, from the base of an exploration well, drilled $15 \mathrm{~km}$ south-southwest off Abidjan in the Deep Ivorian Basin. The authors suggested that shallow marine incursions developed along the Côte d'Ivoire margin in the Albian to Cenomanian, during the early rifting stage of the ProtoSouth Atlantic.

During the drilling of Leg 159, thick basal Cretaceous sedimentary sequences were recovered at Holes 959D, 960A, and 962D, in more distal settings from the African continent, close to the continent/ocean boundary. Some of the sequences contain abundant planktonic and benthic foraminifers, which may provide further insight into the timing of continental separation (de Klasz, 1978; Moullade and Guérin, 1982; Moullade et al., 1993; Bonatti et al., 1996) and the early paleoceanographic evolution of the embryonic equatorial Atlantic. The main aims of this study are, therefore, to document the Lower Cretaceous benthic foraminiferal assemblages from Leg 159 , and to use these data to constrain biostratigraphically the onset

${ }^{1}$ Mascle, J., Lohmann, G.P., and Moullade, M. (Eds.), 1998. Proc. ODP, Sci. Results, 159: College Station, TX (Ocean Drilling Program).

${ }^{2}$ Geologisch-Paläontologisches Institut der Christian-Albrechts-Universität zu Kiel, Olshausenstrasse 40, D-24118 Kiel, Federal Republic of Germany. (Present address: Department of Palaeontology, Natural History Museum, Cromwell Road, London SW7 5BD, United Kingdom.) a.holbourn@nhm.ac.uk

${ }^{3}$ Laboratoire de Micropaléontologie et de Géologie Marines, CNRS UMR 6526 et GDR 88, Université de Nice-Sophia Antipolis, Parc Valrose, 06108 Nice Cedex 2, France. of marine sedimentation and to interpret the early paleoenvironments of the Côte d'Ivoire-Ghana Transform Margin.

\section{LOCATION AND GEOLOGICAL SETTING}

Figure 1 shows the location of all holes where Lower Cretaceous sediments were recovered during the drilling of Leg 159. Hole 959D is situated at $3^{\circ} 37.656^{\prime} \mathrm{N}, 2^{\circ} 44.149^{\prime} \mathrm{W}$, in a water depth of $2090.7 \mathrm{~m}$, on a small plateau close to the top of the Côte d'Ivoire-Ghana Marginal Ridge (CIGMR), which extends along the southern side of the Deep Ivorian Basin. Hole 960A was drilled close to the center of the ridge on the same plateau, $3 \mathrm{mi}$ south of Hole 959D, at $3^{\circ} 35.025^{\prime} \mathrm{N}$, $2^{\circ} 43.990^{\prime} \mathrm{W}$, in a water depth of $2048.3 \mathrm{~m}$. Holes $962 \mathrm{~B}$ and $962 \mathrm{D}$ are located, respectively, at $3^{\circ} 15.063^{\prime} \mathrm{N}, 3^{\circ} 10.919^{\prime} \mathrm{W}$, and $3^{\circ} 15.082^{\prime} \mathrm{N}$, $3^{\circ} 10.898^{\prime} \mathrm{W}$, and in water depths of 4637.0 and $4654.3 \mathrm{~m}$, near the summit of a minor ridge extending southwest of the main CIGMR and north of the oceanic crust, which is covered by a thick sequence of undeformed sediments (Mascle, Lohmann, Clift, et al., 1996, chap. 8, fig. 3).

Comprehensive lithologic and sedimentological descriptions of Lower Cretaceous sedimentary sequences recovered from Holes 959D, 962B, and 962D can be found in Mascle, Lohmann, Clift, et al., 1996. The basal sediments at Holes 959D (lithologic Unit V), 962B (lithologic Unit II), and 962D (lithologic Unit III) were originally dated as late Albian on the basis of nannofossils and planktonic foraminifers, whereas the basal lithologic unit at Hole 960A (lithologic Unit V), which underlies sediments of Turonian-Coniacian age, remained undated (Mascle, Lohmann, Clift, et al., 1996). Mascle, Lohmann, Clift, et al. (1996) suggested that the basal sedimentary units from Holes 959D, 960A, and 962D were post-rift deposits and that strike faulting and uplifting of deepest sequences concurred with sedimentation. These basal sequences, therefore, reflect a complex paleotopography, marked by several fossil ridges, northward prograding sedimentary lenses deposited in developing half-grabens and distal fans along the steeper northern slopes of the CIGMR. According to Mascle, Lohmann, Clift, et al. (1996), the northward progradation of the sediments indicates that the terrigenous components were 
Figure 1. Locations of Sites 959-962.

mainly derived from the Brazilian Shelf, then located just south of the intracontinental transform margin.

\section{METHODS}

A total of 154 samples (approximately $20 \mathrm{~cm}^{3}$ ) from the basal lithologic units of Holes 959D, 960A, 962B, and 962D were analyzed (Table 1). The samples were dried, weighed, soaked in distilled water, wet-sieved through a $63 \mu \mathrm{m}$ screen, and the residue was dried. Very consolidated samples were first treated with a buffered 5\% hydrogen peroxide solution to help break them up before sieving. In rare cases where this hydrogen peroxide treatment did not lead to complete disintegration of the clay, we soaked the dried sample in a concentrated anionic tenside solution (REWOQUAT of REWO Chemie, Steinau an der Strasse, Germany), that usually disintegrated even slightly silicified samples. Generally, the complete residue was picked for benthic foraminifers. In a few exceptional samples with extremely high faunal content, only splits of the samples were picked. Splitting was done with a standard Otto-splitter. Fragments of tubular species were counted as one individual; indeterminable fragments or extremely deformed specimens were picked, but not included in the counts. The foraminiferal slides are housed in the micropaleontology collections of the Geologisch-Paläontologisches Institut at the Christian Albrechts University in Kiel. Electron micrographs were made on a Camscan SEM at the Geologisch-Paläontologisches Institut at the Christian Albrechts University in Kiel. To clarify the biostratigraphic assignations made for each hole, a table was compiled from the literature that shows the stratigraphic ranges of relevant benthic and planktonic foraminiferal species (Fig. 2).

\section{BIOSTRATIGRAPHY}

\section{Hole 959D}

The samples from the basal part of this hole are either barren or contain sparse assemblages of poorly preserved planktonic and benthic foraminifers. The presence of Gavelinella flandrini and Hedbergella infracretacea in Sample 159-959D-71R-1, 30-33 cm, points to a late Aptian or early Albian age for this assemblage (Fig. 2 ). However, some samples below this interval contain a few specimens of Berthelina intermedia, Gavelinella spp., Bolivina sp. 1, ?Spiroplectinella sp. 1, Heterohelix sp. and Schackoina sp., which
Table 1. Summary of samples studied from Holes 959D, 960A, 962B, and 962D.

\begin{tabular}{cccc}
\hline Hole & Core sections & Lith. unit & Samples \\
\hline 959D & 71R-1 to 78R-7 & 5 & 20 \\
960A & 37R-1 to 60R-2 & 5 & 23 \\
962D & 7R-1 to 37-CC & 3 & 92 \\
962B & 7H-1 to 9H-6 & 2 & 19 \\
\hline
\end{tabular}

are also found to occur abundantly at Hole $962 \mathrm{D}$, from Cores 159 962D-37R to 7R. A latest Albian-earliest Cenomanian age is suggested for these assemblages, by the presence of Berthelina intermedia, Bolivina sp. 1, ?Spiroplectinella sp. 1, Heterohelix sp., and Schackoina sp. (Fig. 2).

\section{Hole 960A}

No benthic or planktonic foraminifers were recovered from the basal lithologic unit at this hole, except for a few downhole contaminants.

\section{Hole 962D}

Abundant, small benthic foraminifers as well as planktonic foraminifers, ostracodes, diatoms, and radiolarians are found only in the 63- to 125- $\mu \mathrm{m}$ fraction of most of the samples. Results are shown in Table 2 . The assemblages are predominantly composed of calcareous taxa, but some samples also contain a small agglutinated component. The main calcareous genera are Patellina, Trocholina, Berthelina, Gavelinella, Osangularia, Bolivina, Neobulimina, Laevidentalina, Frondicularia, Lingulina, Globulina, and Quinqueloculina. Agglutinated genera consist mainly of some ?Spiroplectinella and very rare tubular forms. Preservation varies considerably, and marked fluctuations in size, diversity, and abundance of benthic foraminiferal assemblages are observed throughout the sequence. Three main cycles are distinguished in the succession. From Cores 159-962D-9R through $13 \mathrm{R}$, the preservation is consistently poor (planktonic foraminiferal tests are partially dissolved) and benthic foraminiferal diversity and abundance are low. No samples were available for study from Cores 159-962D-14R and 15R, which had extremely low recovery. From Cores $159-962 \mathrm{D}-16 \mathrm{R}$ through $20 \mathrm{R}$, the preservation is mostly good and the benthic assemblages are abundant and diverse. 


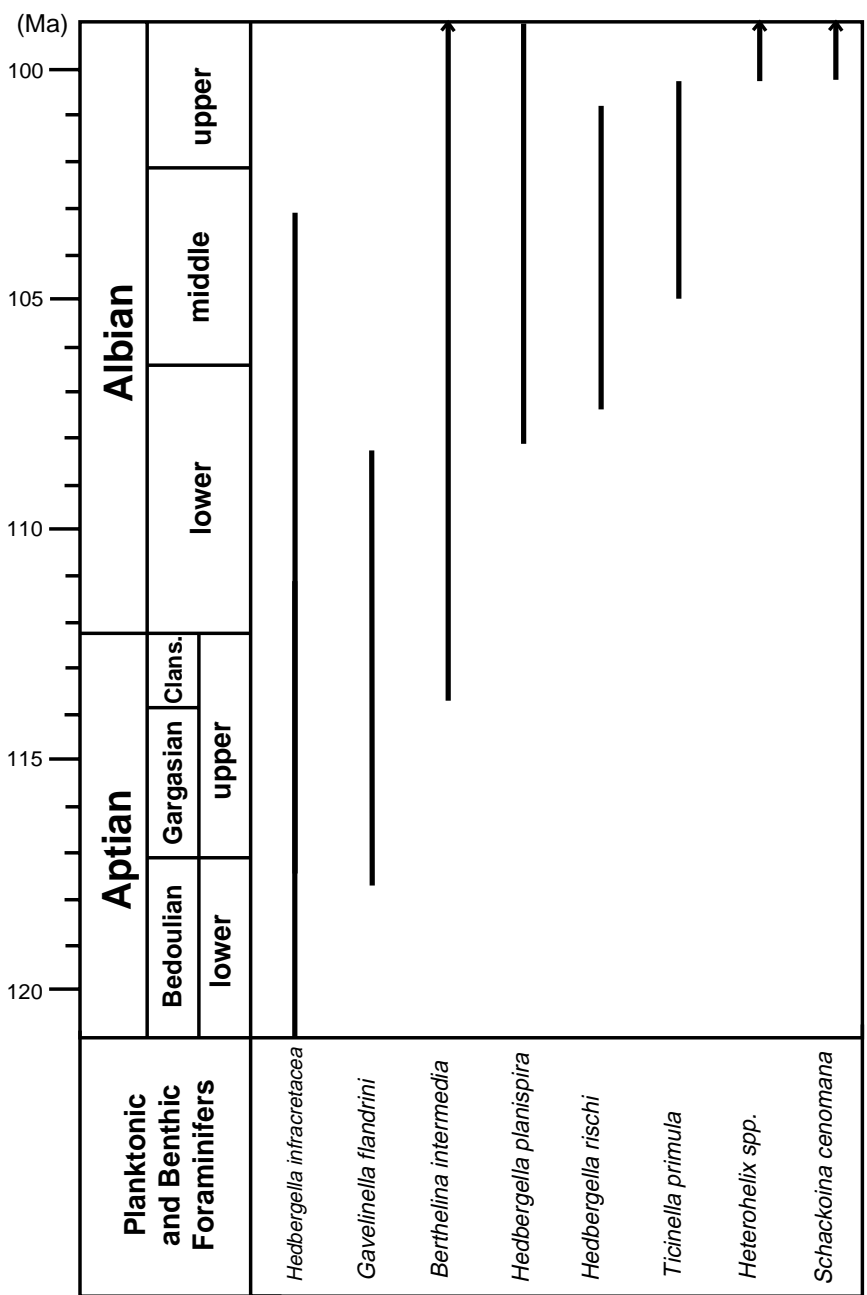

Figure 2. Stratigraphic ranges of age diagnostic planktonic and benthic foraminifers compiled from Moullade (1966, 1974), Robaszynski and Caron (1995). Time scale after Gradstein et al. (1994).

From Cores 159-962D-21R through 37R, the preservation, size, diversity, and abundance of benthic foraminiferal assemblages show great variability. Second-order fluctuations in abundance and diversity can also be detected within the three main cycles.

The foraminiferal biostratigraphy at Hole 962D is problematic, due to the absence of large keeled planktonic foraminifers. However, the co-occurrence of the planktonic foraminifers Hedbergella delrioensis, Schackoina sp., and Heterohelix sp. points to a latest Albian to earliest Cenomanian age for the sequence (Fig. 2). Planktonic assemblages of a slightly older age-including Hedbergella rischi with a late early Albian to late Albian range (Moullade, 1966, 1974), forms transitional to Ticinella primula (mid-Albian), Hedbergella infracretacea with a last appearance datum (LAD) end of mid-Albian (Moullade, 1966, 1974), and Ticinella primula with a mid-Albian to late Albian (early Vraconian) range (Moullade, 1966, 1974; Robaszynski and Caron, 1995)_are also intermittently recorded throughout the sequence, suggesting that the in situ sediment might periodically include allochthonous components derived from older stratigraphic units.

Few stratigraphically significant benthic foraminifers are found in the assemblages from Hole 962D. The genera Spiroplectinella and Neobulimina are not recorded in sediments older than late Albian in the literature. Osangularia is a typical Albian genus, rarely reported from older deposits (Guérin, 1981; Dailey, 1970; 1983; Haig, 1992; Crittenden and Price, 1990), although it does also occur in younger sediments. Some of the more common taxa at Hole 962D (Bolivina sp. 1, ?Spiroplectinella sp.1, and ?Osangularia sp. 2) were left in open nomenclature because they could not be matched with any described species in the literature. These taxa probably indicate some degree of endemism in the benthic foraminiferal assemblages of the basin during the Albian, and the stratigraphic potential of these endemic species remains to be investigated.

\section{Hole 962B}

A high level of dissolution is evident in most of the foraminiferal tests from this site. Planktonic foraminifers as internal molds, including Hedbergella planispira and Hedbergella delrioensis, were found in Sections 159-962B-8H-5 through 9H-6. Rare, benthic foraminifers, including some small gavelinellids and some ?Spiroplectinella, which were found in abundance at Hole 962D, were recovered only in Section 159-962B-9H-4. These, together with small specimens of Hedbergella planispira and Hedbergella delrioensis, indicate a late Albian-earliest Cenomanian age for Section 159-962B-9H-4. Planktonic foraminifers in Sections 159-962B-8H-5 through $8 \mathrm{H}-\mathrm{CC}$ are larger and with a more evolved morphology than in Sections 159962B-9H-2 through 9H-6, suggesting a slightly younger Cenomanian? age for the upper interval. One well-preserved specimen of Stilostomella in Section 159-962B-8H-5, base, points to a Late Cretaceous age. The occurrence of numerous fish teeth in Sample 159962B-8H-5 and in samples from two intervals, 159-962B-8H-4, 0-90 $\mathrm{cm}$, and $8 \mathrm{H}-3,140-150 \mathrm{~cm}$, which also contain glauconite, indicates that accumulation rates were probably very slow, so that the concentration of the most resistant microfossils became enriched over a long time span. Cores 159-962B-7H and $8 \mathrm{H}$ are thus thought to represent condensed sequences, and hiatuses may have occurred during their deposition.

\section{PALEOENVIRONMENTS}

\section{Hole 959D}

The reversed stratigraphical position of the sparse foraminifers found in Hole 959D suggests that marine sediments of a late Aptian to early Albian age were being reworked into younger sediments of a late Albian to early Cenomanian age. Intermixing, or transport by sliding, may have occurred from a nearby uplifted source undergoing rapid erosion, following, for instance, an unroofing event on the tectonically active transform margin of separating plates.

\section{Hole 960A}

In Hole 960A the absence of foraminifers throughout the succession is in agreement with the paleoenvironmental interpretation of lacustrine sediments for lithologic Subunit VB and of brackish marine deposits for lithologic Subunit VA. Palynological evidence also supports this interpretation as spores and pollens are only recovered from lithologic Subunit VB, and rare, poorly preserved dinoflagellates from lithologic Subunit VA (Masure et al., Chap. 24, this volume; Oboh-Ikuenobe et al., Chap. 25, this volume).

\section{Hole 962D}

In Hole 962D, which is situated on a minor ridge extending southwest and in the prolongation of the main CIGMR, the abundant foraminiferal assemblages can be used to constrain both the timing of deposition and the paleobathymetry of the area. Marked fluctuations in test size, abundance, and diversity reflect a pulsed sedimentation pattern with an overall high accumulation rate during the late Albian- 


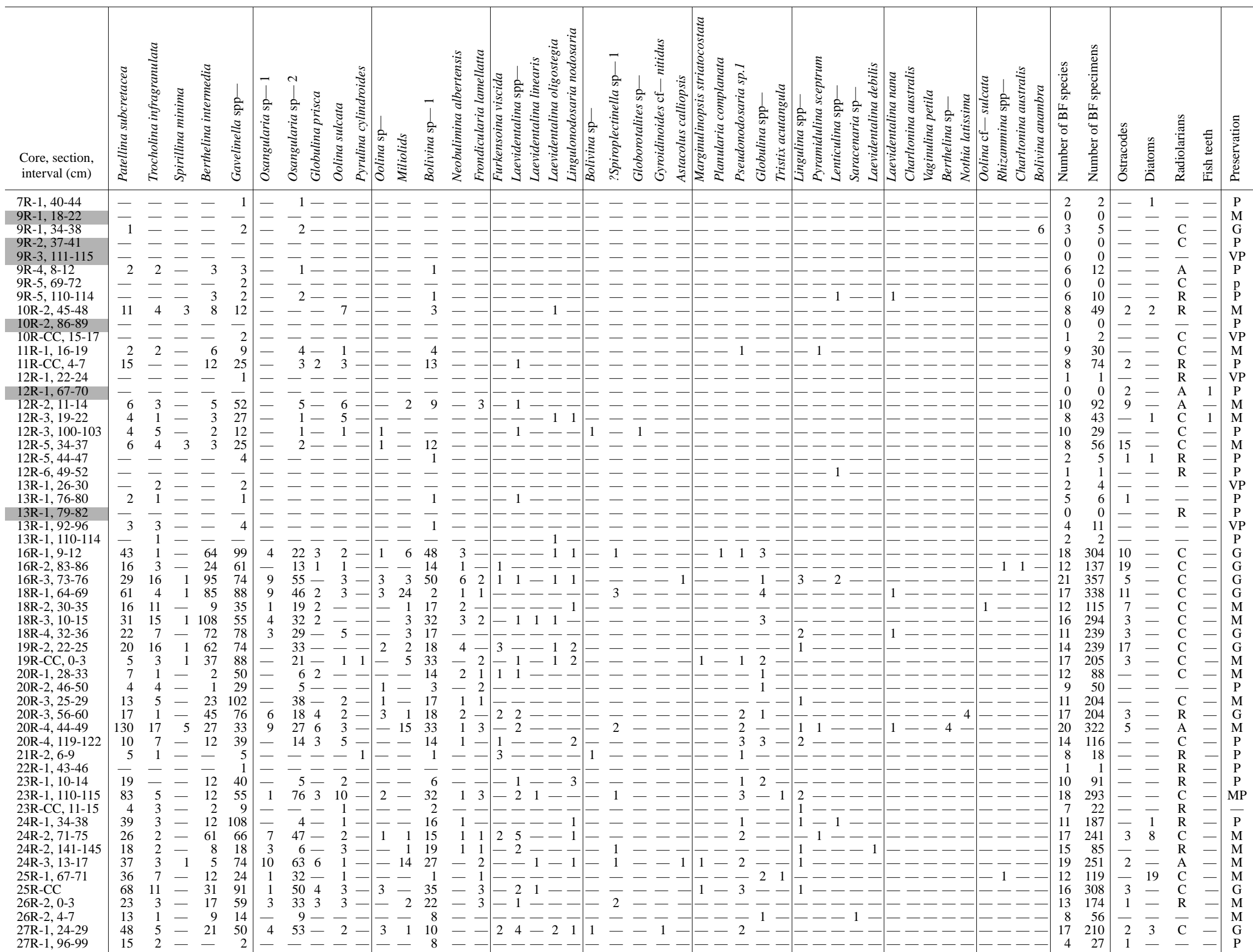


Table 2 (continued).

\begin{tabular}{|c|c|c|c|c|c|c|c|c|c|c|c|c|c|c|c|c|c|c|c|c|c|c|c|c|c|c|c|c|c|c|c|c|c|}
\hline $\begin{array}{l}\text { Core, section, } \\
\text { interval }(\mathrm{cm})\end{array}$ & 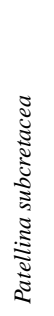 & 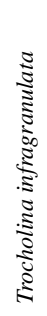 & 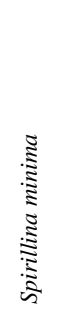 & 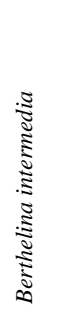 & 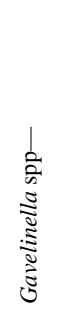 & 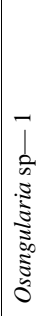 & 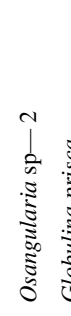 & 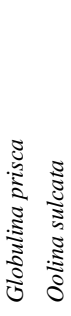 & 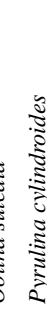 & & 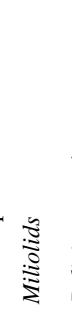 & 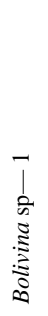 & 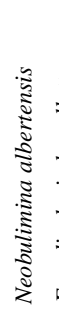 & 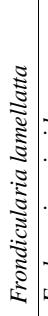 & 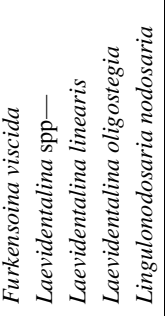 & & 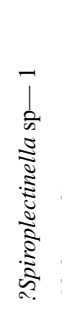 & 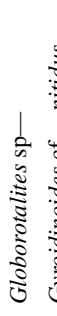 & 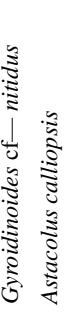 & & 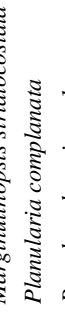 & & 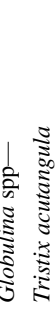 & 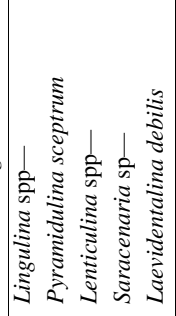 & 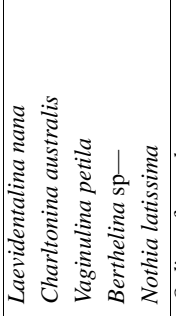 & 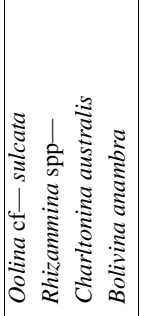 & 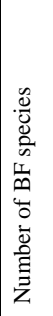 & 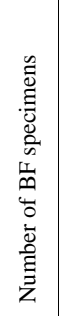 & 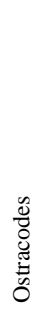 & 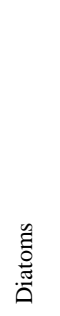 & 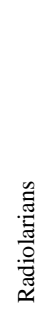 & 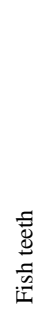 & 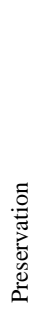 \\
\hline 27R-2, 58-61 & 48 & 4 & - & 26 & 43 & 3 & $11-$ & -4 & 1 & & - - & 5 & - & - & $1----$ & - & - & - & - - & & - - & -- & - - & ----- & ----- & ---- & 10 & 146 & - & 41 & C & - & \\
\hline & & $\overline{0}$ & 5 & 6 & 12 & & & $-\frac{-}{4}$ & - & & -21 & $\begin{array}{l}2 \\
9\end{array}$ & & & $1----$ & - & $\overline{13}$ & - & & & $1-$ & -7 & & $--\frac{-}{1}-$ & $\frac{-1}{2}-\overline{1}$ & $-\overline{1}-二$ & $\begin{array}{r}8 \\
24\end{array}$ & $\begin{array}{r}31 \\
325\end{array}$ & - & 5 & $\mathrm{R}$ & 二 & \\
\hline $\begin{array}{l}2 \\
2\end{array}$ & $\begin{array}{r}53 \\
7\end{array}$ & $\begin{array}{l}9 \\
2\end{array}$ & $\underline{5}$ & $\begin{array}{r}29 \\
2\end{array}$ & $\begin{array}{l}92 \\
16\end{array}$ & 12 & $\begin{array}{r}50- \\
2-\end{array}$ & - 4 & $\overline{1}$ & & -21 & $\begin{array}{l}9 \\
1\end{array}$ & $\begin{array}{l}7 \\
2\end{array}$ & 5 & $\overline{1}-3=-1$ & - & 13 & - & - 1 & & $1 \frac{1}{1}$ & $\frac{3}{-7}$ & & $\begin{array}{l}1-1-二 \\
1-1-二\end{array}$ & $2-1=-$ & $-1-二$ & $\begin{array}{l}24 \\
10\end{array}$ & $\begin{array}{r}325 \\
35\end{array}$ & - & 二 & $\begin{array}{l}\mathrm{R} \\
\mathrm{A}\end{array}$ & 二 & \\
\hline & 15 & 2 & - & 4 & 31 & - & 2 & $1-$ & - & & -- & 1 & 4 & - & $11--1$ & & - & - & -- & & -1 & - & & $-1----$ & ----- & ---- & 12 & 64 & - & & & & \\
\hline & 22 & 2 & - & 18 & 54 & 5 & $26-$ & - & 3 & & -7 & 4 & 3 & - & $3---$ & - & 8 & - & $5-$ & & & - & & ----- & ----- & & 15 & 167 & - & & & & \\
\hline & 3 & - & - & 5 & 6 & & -- & -1 & - & & -- & - & 2 & - & --- & & - & - & - - & & -- & -- & & ----- & ----- & -- & 5 & 17 & - & 2 & & & \\
\hline & 19 & 5 & - & 24 & 95 & 12 & $39-$ & -- & - & - & -1 & 14 & & 5 & $1---$ & - & 2 & - & & & & - & & & & & 14 & 228 & - & 41 & R & & \\
\hline & 32 & 4 & - & 42 & 122 & 8 & $96-$ & -1 & 1 & & & 12 & & & $-1-1-$ & & & - & & & & $\bar{T}$ & & --- & -- & & 13 & 341 & - & 6 & & & \\
\hline & 32 & - & 1 & 29 & 70 & 7 & $47-$ & -2 & 2 & - & -4 & 9 & 8 & 1 & ----1 & - & 5 & - & & & -- & 1 & & $-1 \quad 1--$ & ----- & & 18 & 221 & - & 1 & $\mathrm{C}$ & & $\mathrm{M}$ \\
\hline & & $\overline{2}$ & - & 1 & 8 & - & 10 & $1-$ & - & $-1-$ & -- & 5 & - & - & $3----$ & - & 1 & - & -- & & -- & -1 & -- & ----- & ----- & -- & 8 & 37 & - & - & & & \\
\hline & 21 & 2 & 二 & 9 & 17 & 1 & $5-$ & - 1 & - & & -2 & 16 & - & 1 & $-1-1-$ & - & - & 二 & & & - - & -7 & -二 & -二-二- & -ーーー二 & - - - - & 12 & 77 & - & 1 & $\mathrm{C}$ & & $\stackrel{M}{\mathrm{M}}$ \\
\hline & 13 & 二 & 二 & $\begin{array}{l}3 \\
1\end{array}$ & 11 & $\overline{1}$ & $\begin{array}{l}5-1 \\
4-2\end{array}$ & $=\overline{1}$ & ב & & $-\overline{1}$ & 2 & - & -7 & 二-二-1 & - & & - & & & & - & $-二$ & 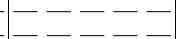 & -ニニ-二 & $=-二-$ & 6 & 31 & - & - & & & \\
\hline & $\overline{3}$ & 二 & - & - & $\begin{array}{r}11 \\
5\end{array}$ & 1 & $\begin{array}{l}4-7-250 \\
4-\end{array}$ & - 1 & - & & -1 & - & - & 1 & ニニ-二- & & - & - & & & & - & & & ----- & ---- & 7 & 20 & - & - & C & & $\stackrel{\mathrm{P}}{\mathrm{P}}$ \\
\hline & 21 & $\overline{13}$ & $\overline{3}$ & $\bar{T}_{1}$ & 19 & $\overline{1}$ & 5 & $\overline{3}=$ & - & & $-z$ & $\overline{23}$ & $\overline{1}$ & $\overline{4}$ & ニニニニ二 & - & & 二 & & & & & & $-1--$ & -二z二二 & $E=-二$ & 3 & 12 & - & - & & - & $\begin{array}{l}\mathrm{P} \\
\mathrm{M}\end{array}$ \\
\hline & & & 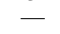 & - & - & & & & & & $-E$ & & - & & 二二ニ二二 & - & - & 二 & & & - - & - & & $-z---$ & ----- & & $\begin{array}{r}11 \\
0\end{array}$ & $\begin{array}{r}94 \\
0\end{array}$ & 二 & - & $\mathrm{R}$ & & P \\
\hline & & & - & & & - & & - & 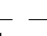 & & -- & 2 & - & - & ----- & - & - & - & & & & - & & ----- & & & 7 & 37 & - & & & & \\
\hline & 24 & & 4 & & & 4 & & 1 & & & & 38 & & 2 & $12-11$ & & 3 & & & & -- & 5 & & 1 & & & 21 & 197 & 1 & & & & \\
\hline & 4 & 2 & 6 & 8 & 14 & 1 & $2-$ & -1 & & & & 14 & 21 & & $-1-1-$ & & - & - & & & & & & $-1-$ & - & & 13 & 72 & 1 & - & & & \\
\hline & 22 & 1 & - & 16 & 2. & & $20-$ & -1 & - & - & -4 & 16 & & 4 & $-2--1$ & & - & 8 & & & -2 & & & & & & 16 & 125 & & & & & \\
\hline & & - & - & 1 & 1 & - & $11-$ & -- & - & - & - - & - & - & & ---- & - & - & -- & & & - & & & -- & & & & & & & & & \\
\hline & 5 & - & - & 2 & 10 & - & $11-$ & -1 & - & & -- & 5 & - & - & ----- & - & 1 & - & & & & -- & -- & ----- & ----- & & 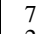 & 35 & & 1 & & & \\
\hline & 2 & - & $\overline{2}$ & $\overline{20}$ & 1 & - & $\overline{30}-7$ & $\overline{3}$ & - & & -- & - & - & $\overline{3}-1$ & $-\frac{-}{2}---$ & & - & & & & & -5 & -- & ----- & ----- & & 2 & $\begin{array}{r}3 \\
16\end{array}$ & - & 2 & & & $P$ \\
\hline & 142 & & 2 & 2 & 6 & 1 & 3 & 3 & - & -1 & - & 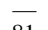 & 2 & 3 & $-2---$ & - & - & - & $--\overline{0}+x+2$ & & -- & $2-$ & $\overline{-1}$ & --- & -- & -1 & 14 & & & E & & & \\
\hline & & 56 & 1 & 11 & 160 & 7 & 103 & 8 & - & & 9 & 81 & 5 & 5 & $-1--5$ & - & 1 & - & -2 & & 11 & 7 & 31 & --- & - & -- & 22 & 587 & 7 & 3 & & & \\
\hline & & 1 & - & 3 & 8 & - & & - & 3 & & -- & - & & & & & - & - & & & -- & -- & & - & - & -- & 8 & 27 & - & 6 & & & \\
\hline & - & - & 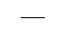 & - & & - & 2 & 1 & - & & -- & - & 1. & - & $1-$ & & - & 1 & & & & & & & & & 6 & & - & & & & \\
\hline & 7 & & & 5 & & & 1 & -- & & & -- & 3 & 2 & - & & & 1 & - & & & & & & & & & & 50 & & - & & & \\
\hline & 8 & 2 & 4 & 4 & 2 & 2 & $13-$ & -- & - & & -3 & 5 & & 1 & -1 & & 1 & & & & & & & & & & 14 & 71 & - & - & & & \\
\hline & - & - & - & 34 & 37 & - & & -1 & - & & - - & 2 & 34 & - & $2-$ & & - & & & & & & & & & & 7 & 118 & - & 1 & & & \\
\hline & 3 & 3 & - & - & 5 & - & -- & -- & - & & - & 1 & & -1 & -- & & & & & & & & & & -- & & 6 & 14 & & - & ? & & \\
\hline & 3 & 1 & - & $\bar{v}$ & 1 & & -- & -- & - & & $-\overline{20}$ & 2 & - & - & $1----$ & & - & & & & & & & & & & & & & & & & \\
\hline & 57 & 26 & 3 & 25 & 133 & 24 & $86-$ & -1 & 1 & & -30 & 62 & 9 & - & $-\begin{array}{lll}-1 & 1 & 1\end{array}$ & 1 & & - & & & & & & & & & 15 & 465 & & & & & 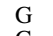 \\
\hline & 4 & 4 & 1 & 6 & 3 & 3 & 13 & $\overline{1}$ & - & - & -1 & 1 & 3 & 1 & & & & & & & & & & & & & 11 & & & - & & & \\
\hline 37R-CC & 22 & 4 & 2 & 9 & 58 & 5 & 28 & $\begin{array}{ll}1 & 1\end{array}$ & 1 & 1 & 4 & 17 & & & ---- & & - & & & & & & & & & & 13 & 153 & - & - & $\mathrm{R}$ & & \\
\hline
\end{tabular}

Notes: $\mathrm{R}=$ rare, $\mathrm{C}=$ common, $\mathrm{A}=$ abundant, $\mathrm{VP}=$ very poor, $\mathrm{P}=$ poor, $\mathrm{M}=$ moderate, $\mathrm{G}=$ good. Shaded samples are barren. 
earliest Cenomanian. Tectonic activity was probably the dominant control on sedimentation rates, and three main cycles of deposition can be detected from overall changes in the preservation, abundance, and diversity of the foraminiferal assemblages, possibly reflecting major shifts in sediment provenance and/or supply. Second-order fluctuations within the three main cycles may be related to variations in sediment accumulation rates, leading to intermittent episodes of dilution.

The foraminiferal assemblages from Hole 962D intermittently contain variable numbers of miliolids, patellinids, and trocholinids, which are characteristic of mid- or inner-shelf settings and some gavelinellids and nodosariids, which are more typical of outer shelf to upper bathyal environments (Eicher et al., 1974; Guérin, 1981; Moullade, 1984). The lack of deep-water agglutinated benthic foraminifers excludes a deeper bathyal environment. The composition of the assemblages indicates that some mixing might have occurred between autochthonous upper bathyal, outer shelf benthic foraminifers, and allochthonous forms originally living in inner- to middle-shelf settings. The intermittent occurrences of diatoms also suggest that at least part of the sediment was periodically redeposited from a proximal, shallower source.

There is no evidence for severe bottom-water dysoxia or anoxia between Cores 159-962D-16R and 37R, as benthic foraminiferal diversity is generally high, except in diluted intervals. The presence of diatoms and radiolarians in the assemblages may indicate enhanced surface-water productivity. However, as little is known about the ecology of these two groups (Thurow and Kuhnt, 1986; Thurow, 1988), such paleoenvironmental interpretation has to remain very speculative. The predominantly small and homogeneous size of benthic calcareous tests may be attributed to the granulometric sorting of allochthonous tests at a distal depositional setting above the carbonate compensation depth (CCD); this is also supported by the fact that only juvenile ostracodes are present in the assemblages. For autochthonous assemblages, the small size can also be attributed to somewhat dysoxic conditions at the seafloor, within a thick nepheloid layer, due to high accumulation rates of organic-rich sediment. From Cores 159-962D-13R through 7R, the high degree of dissolution of planktonic tests and the low abundance of benthic foraminifers suggest that conditions had become more dysoxic at the sediment/water interface during the deposition of the upper part of the sequence.

\section{Hole 962B}

The high level of dissolution of planktonic tests, the virtual absence of benthic foraminifers, and the abundance of radiolarians point to high productivity in surface waters and to severe dysoxia or anoxia at the sediment/water interface with corrosive bottom waters leading to the partial dissolution of planktonic tests. From Section 159-962B-9H-4 upward, several hiatuses may have occurred that may be related to the position of the hole on a topographic high, subjected to erosive submarine currents.

\section{PALEOBIOGEOGRAPHY}

The observed assemblages include an important number of cosmopolitan taxa; however, the presence of some taxa that could not be closely matched to the literature (Bolivina sp. 1, ?Spiroplectinella sp.1, and ?Osangularia sp. 2) and of Bolivina anambra, a typical "African" taxon, suggests that some degree of endemism is present and that circulation may have been restricted during the late Albian in the basin with limited connections to open ocean, and thus with the Tethys. Even a typical Tethyan form such as Berthelina intermedia was also found to be more asymmetrically evolute than morphotypes illustrated from Tethys (Malapris, 1965; Moullade, 1966; Revets,
1996). Most of the nodosariids in the assemblages from Leg 159 are typically found in Tethyan assemblages; however, the absence or rarity of some common Tethyan taxa (ornamented Lenticulina, palmate nodosariid morphotypes, and calcareous agglutinated forms such as Protomarssonella) may also indicate some faunal differentiation. The assemblages from Leg 159 lacked many of the species that typically occur among the "world-wide fauna" described by Riegraf and Luterbacher (1989) in their synthesis of Lower Cretaceous benthic foraminifers from DSDP Legs 1-79. The absence of some common genera listed by Riegraf and Luterbacher (1989) such as Spiroplectammina, Pleurostomella, Pseudoclavulina, and Valvulineria from our samples also points to restricted connections with the world's ocean. Overall, the distinctive composition of the Lower Cretaceous foraminiferal assemblages from Leg 159 reflects a combination of Tethyan, South Atlantic, and local, endemic faunal influences.

The lack of keeled planktonic foraminifers may support a cold water source from high southern latitudes. Alternatively, the absence of keeled bathypelagic planktonic foraminifers may be due to the lack of deep-water circulation between the open ocean and the embryonic South Atlantic in the late Albian or may be interpreted as an indication of shallow depths, leading to the exclusion of deeper subpelagic niches in the water column (Eicher, 1969; Leckie, 1987). This does not contradict observations of bathypelagic planktonic taxa (Moullade et al., 1993; Saint-Marc and N'Da, in press) in the Albian of the neighboring Gulf of Guinea, where open connections to the open sea were better established than in the Côte d'Ivoire-Ghana Transform Margin area, which was fragmented into tectonic sub-basins. The presence of microfossils as old as late Aptian or early Albian, even redeposited ones, demonstrates that marine sedimentation was occurring in the area at that time and strengthens earlier hypotheses by Förster (1978), Wiedmann and Neugebauer (1978), and Moullade and Guérin (1982) of an Early Cretaceous connection between Tethys and the South Atlantic, through the Central Atlantic.

\section{CONCLUSION}

This study extends our knowledge of Lower Cretaceous benthic foraminifers from the African Equatorial Margin and provides a data base for paleoceanographic interpretation and paleogeographic reconstructions. A summary of the biostratigraphy and paleoenvironmental interpretation based on benthic foraminiferal data from Hole 962D is presented in Figure 3. The foraminiferal data establish biostratigraphic constraints for the onset of marine sedimentation on the CIGMR and show that marine conditions already existed by the late Aptian-early Albian near Hole 959D and by mid- to late Albian near Hole 962D. The older marine sequences were subsequently reworked into younger sediments of a late Albian to earliest Cenomanian age at these two holes. The composition of the assemblages suggests mixing between autochthonous outer shelf to upper bathyal and allochthonous inner- to middle-shelf benthic foraminifers. Tectonic activity was probably the overriding control on sediment supply and accumulation rates, leading to a complex patchwork of sedimentary lenses and tectonic slices in developing half-grabens.

The distinctive composition of the benthic foraminiferal assemblages from Holes 959D, 962B, and 962D is characteristic of an outer shelf to upper bathyal setting. It also reflects a combination of Tethyan, South Atlantic, and local, endemic faunal influences, indicating that connections to the open ocean and to the Tethys probably remained restricted during the Albian and early Cenomanian, at least locally (i.e., on the CIGMR). In Hole 962D, there is no evidence for bottom-water anoxia or severe dysoxia between Cores 159-962D$16 \mathrm{R}$ and $37 \mathrm{R}$, although the presence of radiolarians and the intermittent occurrence of diatoms point to high productivity in surface waters. A deterioration in bottom-water oxygenation appears to have occurred during the deposition of the upper part of the sequence from 


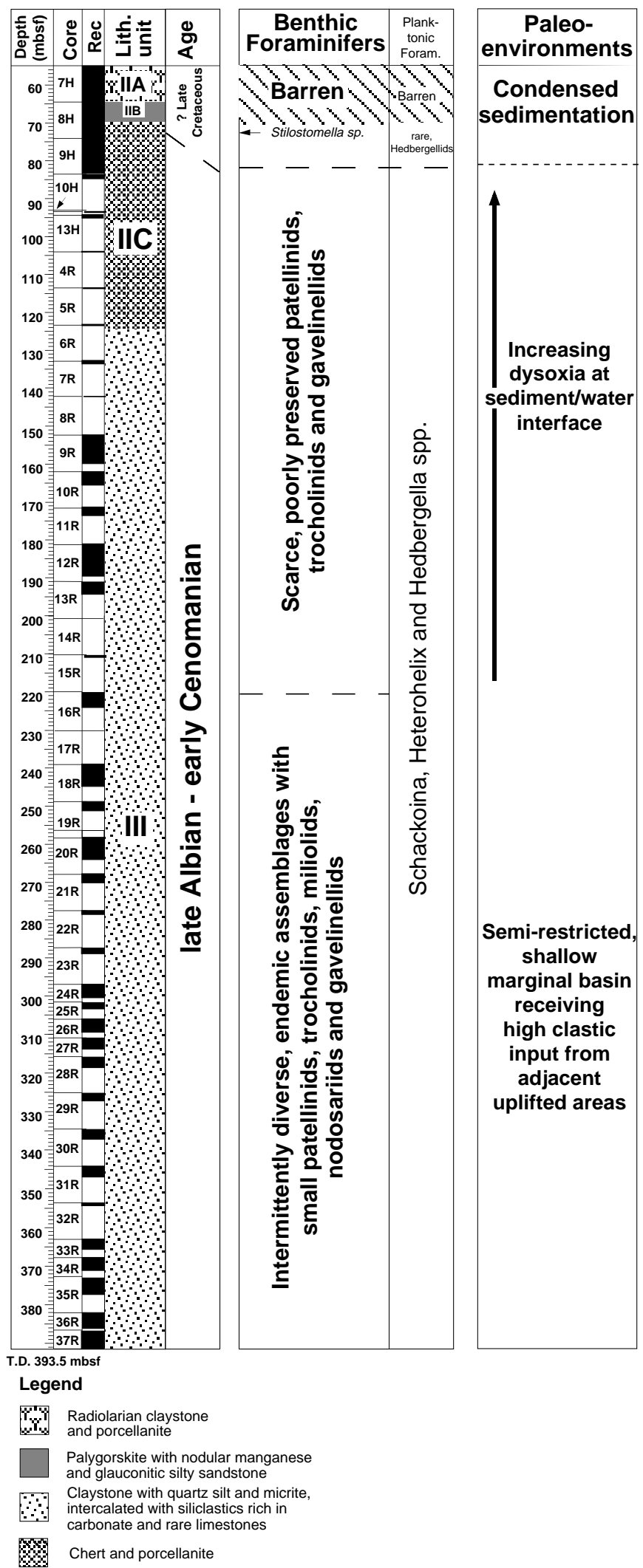

Figure 3. Benthic foraminiferal assemblages from Hole 962D: biostratigraphic and paleoenvironmental summary.
Holes 962D and 962B (Sections 159-962D-7R-1 through 13R-1 and 159-962B-8H-5 through 9H-6). From the Cenomanian onward, a period of nonsedimentation was probably related to the position of the hole on a topographic high along the margin of the Gulf of Guinea, subjected to erosive submarine currents.

\section{SYSTEMATIC NOMENCLATURE}

The benthic foraminiferal classification above the level of superfamily employed here follows the taxonomic classification of Loeblich and Tappan (1992). Below the level of superfamily, the classification of Loeblich and Tappan (1988) has been used with some exceptions, which mainly reflect the generic revision of Rotaliine families, proposed by Revets (1996). Open nomenclature has been used for taxa that do not closely match published descriptions.

Order ASTRORHIZIDA Lankester, 1885

Superfamily ASTRORHIZACEA, Brady, 1881

'Family Rhabdamminidae Brady, 1884

Subfamily Rhabdammininae Brady, 1884

Genus Nothia Pflaumann, 1964

Nothia latissima (Grzybowski, 1898)

Plate 1, Figure 1

Dendrophrya latissima GRZYBOWSKI, 1898, p. 17, pl. 10, fig. 8.

Nothia latissima (Grzybowski) KAMINSKI and GEROCH, 1993, pl. 1, figs.

$1,14$.

Description. A wide, flattened tube with a thin wall.

Range and Occurrence. Four fragments found in Sample 159-962D$20 \mathrm{R}-3,56-60 \mathrm{~cm}$. Commonly recorded in flysch-type assemblages (Kaminski and Geroch, 1993).

\section{Genus Rhizammina Brady, 1879}

Rhizammina spp.

Description. We included in this group all finely to medium agglutinated, flattened tubes.

Range and Occurrence. Very rare at all holes.

Order LITUOLIDA Lankester, 1885

Superfamily AMMODISCACEA Reuss, 1862

Family AMMODISCIDAE Reuss, 1862

Subfamily AMMOVERTELLININAE Saidova, 1981

Genus Glomospira Rzehak, 1885

Glomospira charoides (Jones and Parker, 1860)

Plate 1, Figure 5

Trochammina squamata var. charoides Jones and Parker, 1860, p. 304.

Glomospira charoides corona Cushman and Jarvis. Weidich, 1990, pl. 34, figs. 8,9 .

Description. Tubular test, coiling about a vertical axis, with four to five whorls in the outermost layer of coils. Aperture at open end of tube.

Range and Occurrence. A few specimens found in Sections 159-962B$8 \mathrm{H}-\mathrm{CC}, 159-962 \mathrm{~B}-8 \mathrm{H}-6$, and $159-962 \mathrm{~B}-8 \mathrm{H}-4$

\section{Superfamily SPIROPLECTAMMINACEA Cushman, 1927 \\ Family Spiroplectamminidae Cushman, 1927 \\ Subfamily Spiroplectammininae Cushman, 1927 \\ Genus Spiroplectinella Kisel'man, 1972}

\section{?Spiroplectinella $\mathrm{sp} .1$}

Plate 1, Figures 2-4

Description. Elongate, flaring test, with lozenge-shaped cross section and small, initial planispiral whorl, followed by biserial stage. Low, broad chambers separated by thick, slightly raised sutures. Wall smoothly cemented with calcareous cement. Arched aperture at base of last chamber. 
Remarks. Only tentatively assigned to the genus Spiroplectinella, as wall structure is unknown. Initial planispiral whorl is only present in microspheric specimens.

Range and Occurrence. Common in some samples in Hole 962D.

Order SPIRILLINIDA Gorbachik and Mantsurova, 1980 Suborder INVOLUTININA Hoenegger and Piller, 1977 Family Involutinidae Bütschli, 1880

Subfamily Involutininae Bütschli, 1880

Genus Trocholina Paalzow, 1922

Trocholina infragranulata Noth, 1951

Plate 1, Figures 9, 12

Trocholina infragranulata Noth, 1951, pl. 1, fig. 32.

Trocholina infragranulata Noth. Weidich, 1990, pl. 29, figs. 32, 34.

Trocholina infragranulata infragranulata Noth. Neagu, 1975, pl. 96, figs. 1-

$12,25-26,29-30$.

Description. Low, conical, perforate test, evolute on dorsal side with all whorls of tubular second chamber visible. Large umbilicus with pillars surrounded by final whorl on ventral side. Aperture at open end of tube.

Range and Occurrence. Berriasian to early Aptian in the northern Alps (Weidich, 1990). Common in Hole 962D.

Suborder SPIRILLININA Hoenegger and Piller, 1975

Family Patellinidae Rhumbler, 1906

Subfamily Patellininae Rhumbler, 1906

Genus Patellina Williamson, 1858

Patellina subcretacea Cushman and Alexander, 1930 Plate 1, Figures 8, 11

Patellina subcretacea Cushman and Alexander, 1930, pl. 3, fig. 1a, b.

Patellina subcretacea Cushman and Alexander. Neagu, 1975, pl. 82, figs. 1-

16; pl. 85, figs. 26-29. Basov and Krasheninnikov, 1983, pl. 4, fig. 2.

BOLLI et al., 1994, pl. fig. 25.30-32.

Description. Conical, perforate test, evolute on spiral side with two chambers per whorl, separated by carinate, spiral sutures. Peripheral grooves, nodes and aperture distinct on ventral side of better preserved specimens.

Remarks. Tests from Hole 962D vary in height. Also close to Patellina africana, described from the middle-upper Albian of Zululand by Lambert and Scheibnerová (1974).

Range and Occurrence. Berriasian to Albian in Europe (Bartenstein and Brand, 1951; Magniez-Jannin, 1975; Neagu, 1975; Weidich, 1990), Hauterivian to Albian in Indian Ocean (Holbourn and Kaminski, 1997). Common in Hole 962D.

Family Spirillinidae Reuss and Fritsch, 1861 Genus Spirillina Ehrenberg, 1843

Spirillina minima Schacko, 1897

Plate 1, Figures 7, 10

Spirillina minima Schacko, 1897; pl. 1, fig. 4.

Spirillina minima Schacko. Bartenstein and Kovatcheva, 1982, pl. 4, figs. 3839 ; pl. 5, figs. 43-44.

Description. Discoidal, perforate test with small proloculus and planispirally coiled, tubular second chamber. Aperture simple and terminal.

Range and Occurrence. Widely recorded from Lower Cretaceous sediments.

Order MILIOLIDA Lankester, 1885

Suborder MILIOLINA Delage and Hérouard, 1896

Superfamily MILIOLACEA Ehrenberg, 1839

Family Spiroloculinidae Wiesner, 1920

Genus Quinqueloculina d'Orbigny, 1926

Quinqueloculina sp.

Plate 1, Figures 13, 14
Description. Ovate test, usually with five chambers (half coil in length) visible on the outside.

Order LAGENIDA Lankester, 1885 Superfamily ROBULOIDACEA Reuss, 1863

Family ICHTHYOLARIIDAE Loeblich and Tappan, 1988 Genus Lingulonodosaria A. Silvestri, 1903

Lingulonodosaria nodosaria (Reuss, 1863) Plate 2, Figure 6

Lingulina nodosaria Reuss, 1863, pl. 5, fig. 12.

Lingulonodosaria nodosaria (Reuss). Scheibnerová, 1976, pl. 36, fig. 1

Lingulonodosaria nodosaria (Reuss). Meyn and Vespermann, 1994, pl. 5, figs. $8-11$; pl. 6 , figs. $1-3$.

Description. Rectilinear, uniserial test with broad chambers separated by straight, slightly depressed sutures, elliptical cross section and terminal slit aperture.

Range and Occurrence. Cosmopolitan in the Early Cretaceous.

Superfamily NODOSARIACEA Ehrenberg, 1836

Family Nodosariidae Ehrenberg, 1838

Subfamily Nodosariinae Ehrenberg, 1838

Genus Laevidentalina Loeblich and Tappan, 1988

Laevidentalina debilis (Berthelin, 1880)

Plate 2, Figure 11

Marginulina debilis Berthelin, 1880, pl. 3, fig. 28.

Lenticulina (Vaginulina) debilis (Berthelin). Moullade, 1984, pl. 3, fig. 13.

Description. Elongate, uniserial, narrow test with ventrally inflated chambers, separated by depressed, inclined sutures. Terminal, radiate aperture.

Range and Occurrence. Cosmopolitan in the Early Cretaceous.

Laevidentalina linearis (Roemer, 1841)

Nodosaria linearis Roemer, 1841, pl., 15, fig. 5.

Laevidentalina linearis (Roemer). Meyn and Vespermann, 1994, pl. 7, figs. $1-7$.

Description. Elongate, curved, uniserial test with subcylindrical chambers separated by straight, depressed sutures. Terminal radiate aperture.

Range and Occurrence. Valanginian to Albian in northwestern Germany (Meyn and Vespermann, 1994).

Laevidentalina oligostegia (Reuss, 1845)

Plate 2, Figure 1

Nodosaria oligostegia Reuss, 1845, pl. 13, figs. 19-20.

Dentalina oligostegia (Reuss). Haig, 1982, pl. 1, figs. 8-10.

Description. Elongate, uniserial test with two or three ovate chambers, separated by markedly depressed sutures. Last chamber elongated towards a radiate aperture.

Range and Occurrence. Cosmopolitan in the Early Cretaceous.

Genus Pseudonodosaria Boomgaart, 1949

Pseudonodosaria sp. 1

Plate 2, Figure 2

Description. Elongate, uniserial, ovate test with overlapping chambers increasing rapidly in size. Last chamber inflated, much larger than previous ones. Aperture radiate and terminal.

Range and Occurrence. Common in Hole 962D.

Genus Pyramidulina Fornasini, 1894

Pyramidulina sceptrum (Reuss, 1863)

Plate 2, Figure 3 
Nodosaria (Nodosaria) sceptrum Reuss, 1863, pl. 2, fig. 3.

Pyramidulina sceptrum (Reuss) Meyn and Vespermann, 1994, pl. 12, figs. 114; pl. 13, figs. 1-16; pl. 14, figs. 1-17.

Description. Elongate, uniserial test with inflated chambers, ornamented by fine, longitudinal costae and separated by depressed sutures. Aperture simple and terminal.

Remarks. Found mostly as fragments in Hole 962D.

Range and Occurrence. Cosmopolitan in the Early Cretaceous.

Subfamily Lingulininae Loeblich and Tappan, 1961 Genus Lingulina d'Orbigny, 1826

\section{Lingulina spp.}

Description. Elongate, compressed, uniserial tests with overlapping chambers and terminal slit aperture.

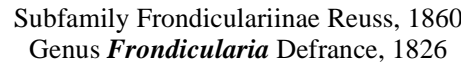

Subfamily Frondiculariinae Reuss, 1860

Genus Frondicularia Defrance, 1826

Frondicularia lamellata Tappan, 1940 Plate 2, Figure 5

Lingulina lamellata Tappan, 1940, pl. 16, fig. 19.

Frondicularia lamellata Tappan. Haig, 1982, pl. 3, figs. 25-29.

Description. Compressed, lanceolate test with low chambers, increasing irregularly in width, separated by arched, depressed sutures. Terminal slit-like aperture.

Range and Occurrence. Originally described from the Cenomanian of the Gulf Coast, U.S.A., by Tappan (1940), also recorded by Haig (1982) from the upper Albian of Queensland.

\section{Genus Tristix Macfayden, 1941.}

Tristix acutangula (Reuss, 1863)

Plate 2, Figure 4

Rhabdogonium acutangulum Reuss, 1863, pl. 4, fig. 14a, b.

Tristix acutangula (Reuss). Tronchetti and Grosheny, 1991, pl. 4, fig. 3. Meyn and Vespermann, 1994, pl. 20, figs. 8-13; pl. 21, figs. 1-4, 6-10; pl. 22, figs. 1, 2.

Description. Elongate, uniserial test, triangular in cross section with slightly concave lateral faces and low chambers separated by arched, depressed sutures. Terminal, circular aperture.

Range and Occurrence. Cosmopolitan in the Early Cretaceous according to Bartenstein and Bolli (1986).

Family Vaginulinidae Ehrenberg, 1838

Subfamily Lenticulininae Chapman, Parr and Collins, 1934

Genus Lenticulina Lamarck, 1804

Lenticulina spp

Plate 2, Figure 7

Description. Involute, lenticuline tests with radiate, terminal aperture.

Range and Occurrence. Rare in Hole 962D.

Genus Marginulinopsis A. Silvestri, 1904

Marginulinopsis jonesi (Reuss, 1863)

Plate 2, Figure 8

Marginulina jonesi Reuss, 1863, pl. 5, fig. 19.

Marginulinopsis jonesi (Reuss) Meyn and Vespermann, 1994, pl. 31, figs. 58; pl. 31, figs. 1-14: pl. 33, figs. 1-14.

Description. Small, robust, elongate test, ornamented by thick, longitudinal ribs with three inflated chambers in the evolute portion. Radiate aperture at peripheral angle.

Range and Occurrence. One specimen found in Sample 159-959D-71R$1,30-33 \mathrm{~cm}$.
Marginulinopsis striatocostata (Reuss, 1863)

Plate 2, Figure 20

Marginulina striatocostata Reuss, 1863, pl. 6, fig. 2.

Marginulinopsis striatocostata (Reuss) Meyn and Vespermann, 1994, pl. 33, figs. $15-20$; pl. 34, figs. 1-6.

Description. Elongate test ornamented by fine, longitudinal ribs, with three to four inflated chambers in the evolute portion, separated by depressed sutures. Radiate aperture at peripheral angle.

Range and Occurrence. Late Valanginian to middle Albian in northwestern Germany (Meyn and Vespermann, 1994). A few specimens found in Hole 962D.

Genus Saracenaria Defrance, 1824

Saracenaria sp.

Description. Elongate, triangular, finely striated test, with rounded ventral margins. Three chambers in the evolute portion are separated by slightly depressed, slanting sutures. Radiate, terminal aperture.

Range and Occurrence. One specimen found in Sample 159-962D-26R$2,4-7 \mathrm{~cm}$.

Subfamily Marginulininae Wedekind, 1937

Genus Astacolus de Montfort, 1808

Astacolus calliopsis (Reuss, 1863)

Plate 2, Figure 10

Marginulina calliopsis Reuss, 1863, pl. 5, fig. 16.

Astacolus calliopsis (Reuss). Bartenstein and Bolli, 1986, pl. 4, figs. 9, 10. Meyn and Vespermann, 1994, pl. 40, figs. 15, 16; pl. 41, figs. 1-15.

Description. Elongate, gently curved test with ventrally inflated chambers, separated by slightly depressed, inclined sutures. Radiate, terminal aperture.

Range and Occurrence. A cosmopolitan species in the Early Cretaceous.

Genus Planularia Defrance, 1826

Planularia complanata (Reuss, 1845)

Plate 2, Figures 12, 13

Cristellaria complanata Reuss, 1845, pl. 13, fig. 54a, b.

Planularia complanata (Reuss). Magniez-Jannin, 1975, pl. 9, figs. 26-38 and text fig. 83. Holbourn and Kaminski, 1995, pl. 13, figs. 4-6.

Description. Flattened "fan-shaped" test with low chambers separated by curved, limbate sutures. Radiate, terminal aperture.

Range and Occurrence. Cosmopolitan in the Early Cretaceous.

Genus Vaginulina d'Orbigny, 1826

Vaginulina petila (Eicher and Worstell, 1970)

Citharina petila Eicher and Worstell, 1970, pl. 2, figs. 20, 21.

Vaginulina petila (Eicher and Worstell). Haig, 1982, pl. 6, figs. 7-10. Holbourn and Kaminski, 1995, pl. 14, fig. 5 .

Description. Elongate, curved test, ornamented by few fine, slanting costae. Ventrally inflated chambers, separated by inclined, depressed sutures. Last chamber elongated towards a terminal, radiate aperture.

Range and Occurrence. One specimen found in Sample 159-962D-28R$1,92-96 \mathrm{~cm}$.

Superfamily POLYMORPHINACEA d'Orbigny, 1839 (nom. transl. Grigelis, 1980)

Family POLYMORPHINIDAE d'Orbigny, 1839

Subfamily POLYMORPHININAE d'Orbigny, 1839

Genus Globulina d'Orbigny, 1839

Globulina prisca (Reuss, 1863)

Plate. 2, Figure 9 
Polymorphina prisca Reuss, 1863, pl. 8, fig. 8.

Globulina prisca (Reuss). Bartenstein and Brand, 1951, pl. 10, fig. 286. Fowler and Braun, 1993, pl. 9, figs. 8-10.

Description. Elongate, ovate test with overlapping chambers arranged along three planes and separated by flush or slightly depressed sutures. Radiate, terminal aperture.

Range and Occurrence. Cosmopolitan in the Early Cretaceous.

Genus Pyrulina d'Orbigny, 1839

Pyrulina cylindroides (Roemer, 1838)

Polymorphina cylindroides Roemer, 1838, pl. 3, fig. 26a, b.

Pyrulina cylindroides (Roemer). Mcneil and Caldwell, 1981, pl. 17, fig. 16. Holbourn and Kaminski, 1995, pl. 15, fig. 10.

Description. Fusiform test with overlapping chambers separated by flush sutures. Radiate, terminal aperture.

Range and Occurrence. Cosmopolitan in the Early Cretaceous.

Family Ellipsolagenidae A. Silvestri, 1923

Subfamily Oolininae Loeblich and Tappan, 1961

Genus Oolina d'Orbigny, 1839

Oolina sulcata (Walker and Jacob, 1798)

Plate 2, Figures 14, 15

Serpula sulcata Walker and Jacob, 1798, pl. 14, fig. 5.

Lagena cf. sulcata (Walker and Jacob). Bartenstein and Brand, 1951, pl. 10, fig. 281.

Lagena sulcata (Walker and Jacob). Petters, 1982, pl. 5, fig. 33.

Description. Unilocular, globular test ornamented by longitudinal ribs. Simple, terminal aperture at the end of a short neck.

Range and Occurrence. Cosmopolitan in the Early Cretaceous.

Oolina cf. sulcata (Walker and Jacob, 1798)

Remarks. Differs from O. sulcata (Walker and Jacob) by having a less globular shape and fewer costae.

Order BULIMINACEA Fursenko, 1958

Superfamily BULIMINACEA Jones, 1875

Family BOLIVINITIDAE Cushman, 1927

Subfamily BOLIVINITINAE Cushman, 1927

Genus Bolivina d'Orbigny, 1839

Bolivina anambra Petters, 1982

Plate 2, Figures 16, 17

Bolivina anambra Petters, 1982, pl. 11, figs. 21, 22, 29.

Description. Small, elongate, biserial test with slightly lobulate periphery. Low chambers overlapping in central part of test are separated by curved, slightly depressed sutures. Narrow aperture on face of terminal chamber.

Range and Occurrence. Originally described by Petters (1982) from the lower Turonian of Nigeria. Six specimens found at the top of the studied sequence in Hole 962D (Sample 159-962D-9R-1, 34-38 cm).

Bolivina sp. 1

Plate 2, Figures 18, 19

Description. Elongate, flattened, biserial test with low chambers separated by slightly depressed, slanting sutures. Later chambers overlap markedly in central part of the test. Loop-shaped aperture bordered by a lip on face of terminal chamber.

Remarks. Toothplate indistinct in our specimens.

Range and Occurrence. Common in Hole 962D.

Subfamily FURSENKOININAE Loeblich and Tappan, 1961 Genus Fursenkoina Loeblich and Tappan, 1961
Fursenkoina viscida (Khan, 1950)

Virgiluna viscida Khan, 1950, pl. 2, figs. 3-5.

Cassidella viscida (Khan). Magniez-Jannin, 1975, pl. 15, figs. 12, 13. Weidich, 1990, pl. 49, figs. 5, 6.

Description. Elongate, narrow, biserial test, slightly twisted at the base. Chambers separated by curved, depressed sutures. Slit aperture on face of final chamber.

Remarks. Toothplate indistinct in our specimens due to poor preservation. An application to the ICZN to remove Cassidella in favor of Fursenkoi$n a$ is pending (Revets, 1996).

Range and Occurrence. Middle to late Albian in Kent (Khan, 1950) and northern Alps (Weidich, 1990), late Albian in the Aube region of France (Magniez-Jannin, 1975). Rare in Hole 962D.

Superfamily TURRILINACEA Cushman, 1927

Family Turrilinidae Cushman, 1927

Genus Neobulimina Cushman and Wickenden, 1928

Neobulimina albertensis (Stelck and Wall, 1954)

Plate 3, Figure 1

Guembelitria cretacea albertensis Stelck and Wall, 1954, pl. 2, fig. 19. Neobulimina albertensis (Stelck and Wall). McNeil and Caldwell, 1981, pl. 18, figs. 2, 3. Haig, 1982, pl. 9, figs. 10-20.

Description. Elongate test, initially triserial, becoming biserial. Subglobular chambers separated by depressed sutures. Loop-shaped aperture on face of terminal chamber.

Remarks. Toothplate indistinct in our specimens.

Range and Occurrence. Cenomanian-Coniacian in North America (McNeil and Caldwell, 1981), late early to late Albian in Queensland (Haig, 1982).

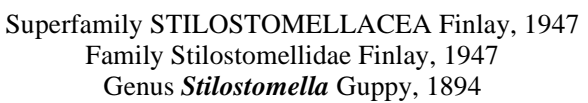

Stilostomella sp.

Plate 3, Figure 8

Description. Rectilinear, uniserial test with subglobular chambers separated by constricted sutures. Wall hispid.

Range and Occurrence. One specimen found at the base of Section 159962B-8H-5.

Order ROTALIIDA Lankester, 1885

Superfamily CHILOSTOMELLACEA Brady, 1881

Family ALABAMINIDAE Hofker, 1951

Genus Charltonina Bermúdez, 1952

Charltonina australis Scheibnerová, 1978

Charltonina australis Scheibnerová, 1978, pl. 5, figs. 2-5.

Charltonina australis Scheibnerová. Haig, 1992, pl. 3, figs. 12, 13.

Description. Trochospiral test with lobulate, carinate periphery. Chambers separated by slightly depressed sutures, strongly oblique on spiral side. Interiomarginal slit aperture.

Range and Occurrence. Aptian-Cenomanian in Indian Ocean (Holbourn and Kaminski, 1997). One poorly preserved specimen found in Sample 159962D-16R-2, 83-86 cm.

Genus Globorotalites Brotzen, 1942

Globorotalites sp.

Description. Trochospiral test with flattened dorsal side and strongly convex umbilical side. Chambers separated by sutures, raised and limbate dorsally, gently curved and depressed ventrally. Interiomarginal slit aperture, extending to deep sulcus. 
Genus Osangularia Brotzen, 1940

Osangularia sp. 1

Plate 3, Figures 2, 3.

Description. Trochospiral, planoconvex test with flattened ventral side. Twelve chambers in last whorl are separated by thick sutures, strongly curved dorsally. Interiomarginal, L-shaped slit aperture extends from umbilicus to periphery.

Range and Occurrence. Common in Hole 962D.

? Osangularia sp. 2

Plate 3, Figures 4, 5, 6 .

Description. Trochospiral, asymmetrically biconvex to near planoconvex test with flattened ventral side. Seven chambers in last whorl surround umbilical boss and are separated by sutures, which are straight and markedly depressed ventrally, and curved dorsally. Interiomarginal slit aperture.

Remarks. Only tentatively assigned to the genus Osangularia on account of its atypical aperture (see Revets, 1996).

Range and Occurrence. Common in Hole 962D.

Family Gavelinellidae Hofker, 1956

Genus Berthelina Malapris, 1965

Berthelina intermedia (Berthelin, 1880)

Plate 3, Figures 9, 10, 14

Anomalina intermedia Berthelin, 1880, pl. 4, fig. 14

Berthelina intermedia (Berthelin). Haig and Lynch, 1993, pl. 4, figs. 26-28.

Revets, 1996, pl. 8, figs. 1-4.

Description. Trochospiral test, slightly flattened on spiral side with rounded periphery and relict apertural flaps, partially covering the umbilicus. Chambers separated by curved, slightly depressed sutures. Interiomarginal aperture, bordered by lip.

Range and Occurrence. Widely recorded worldwide in Albian sediments. Common in Hole 962D.

Genus Gavelinella Brotzen, 1942

Gavelinella flandrini Moullade, 1960

Gavelinella flandrini Moullade, 1960, pl. 2, figs. 10-14. Moullade, 1984, pl. 6 , figs. $1-3$

Description. Trochospiral, compressed test with rounded periphery. Chambers separated by depressed sutures. Interiomarginal aperture, bordered by a lip and partially covered by flaps extending into the umbilical area.

Range and Occurrence. One specimen found in Sample 159-959D-71R$1,30-33 \mathrm{~cm}$.

Gavelinella spp.

Plate 3, Figures 7, 11.

Description. We included in this group all small, trochospiral tests, evolute dorsallly and flattened, involute, ventrally with angled or subrounded periphery, open, depressed umbilicus and interiomarginal slit aperture bordered by a lip, extending from the umbilicus to the periphery.

Range and Occurrence. Common in Hole 962D.

\section{Genus Gyroidinoides Brotzen, 1942}

Gyroidinoides cf. nitidus (Reuss, 1845)

Plate 3, Figure 15.

Rotalina nitida Reuss, 1845, pl. 8, fig. 52, pl. 12, figs. 8, 20.

Gyroidinoides nitidus (Reuss). Basov and Krasheninnikov, 1983, pl. 9, figs. 2,3 .

Description. Trochospiral, subspherical test, with flattened spiral side and strongly convex umbilical side. Five or six chambers in last whorl separated by flush or slightly depressed sutures. Interiomarginal slit aperture close to the periphery.
Range and Occurrence. Gyroidinoides nitidus is typically a Late Cretaceous taxon, widely recorded from Upper Cretaceous sediments of Europe, North and South America (McNeil and Caldwell, 1981), Russia, and the Atlantic Ocean (Basov and Krasheninnikov, 1983). Rare in Hole 962D. Some large specimens found in Sample 159-962D-29R-1, 60-63 cm.

\section{ACKNOWLEDGMENTS}

We are especially grateful to Bill Sliter and Helen Thomas for reviewing the manuscript and to Thomas Pletsch and Wolfgang Kuhnt for their very helpful comments and discussions. We extend our thanks to the staff of the SEM Lab and Photographic Unit at the Geologisch-Paläontologisches Institut of the Christian Albrechts University in Kiel. AELH acknowledges support of a Royal Society European Exchange Fellowship at Kiel University. This is contribution number 131 of the UMR-CNRS "Geosciences Azur," Nice.

\section{REFERENCES}

Bartenstein, H., and Bolli, H.M., 1986. The Foraminifera in the Lower Cretaceous of Trinidad, W.I. Part 5: Maridale Formation, upper part; Hedbergella rohri zone. Eclogae Geol. Helv., 7:945-999.

Bartenstein, H., and Brand, E., 1951. Mikropalaontologische Untersuchungen zur Stratigraphie des nordwestdeutschen Valendis. Abh. Senckenb. Naturforsch. Ges., 485:239-336.

Bartenstein, H., and Kovatcheva, T., 1982. A comparison of Aptian Foraminifera in Bulgaria and North West Germany. Eclogae Geol. Helv., 75:621667.

Basov, I.A., and Krasheninnikov, V.A., 1983. Benthic foraminifers in Mesozoic and Cenozoic sediments of the southwestern Atlantic as an indicator of paleoenvironment, Deep Sea Drilling Project Leg 71. In Ludwig, W.J., Krasheninnikov, V.A., et al., Init. Repts. DSDP, 71: Washington (U.S. Govt. Printing Office), 739-788.

Berthelin, G., 1880. Mémoire sur les foraminifères fossiles de l'Etage Albien de Moncley (Doubs). Mem. Soc. Geol. Fr., Ser.3, 1:1-84.

Bolli, H.M., Beckmann, J.-P., and Saunders, J.B., 1994. Benthic Foraminiferal Biostratigraphy of the South Caribbean Region: Cambridge (Cambridge Univ. Press).

Bonatti, E., Ligi, M., Borsetti, A.M., Gasperini, L., Negri, A., and Sartori, R., 1996. Lower Cretaceous deposits trapped near the equatorial Mid-Atlantic Ridge. Nature, 380:518-520.

Castelain, J., Faulkner, J.S., de Klasz, I., Meijer, M., and Rérat, 1962. Répartition stratigraphique d'Afrobolivina afra Reyment dans quelques bassins côtiers de l'Afrique Occidentale. Rev. Micropaleontol., 5:54-58.

Crittenden, S., and Price, R.J., 1990. The foraminiferid Osangularia schloenbachi (Reuss, 1863): the erection of a neotype. J. Micropalaeontol., 9:253-255.

Cushman, J.A., and Alexander, C.I., 1930. Some Vaginulinas and other foraminifera from the Lower Cretaceous of Texas. Contrib. Cushman Lab. Foraminiferal Res., 6:1-10.

Dailey, D.H., 1970. Some new Cretaceous foraminifera from the Budden Canyon Formation, northwestern Sacramento Valley, California. Contrib. Cushman Found. Foraminiferal Res., 21:100-111.

1983. Late Cretaceous and Paleocene benthic foraminifers from Deep Sea Drilling Project Site 516, Rio Grande Rise, western South Atlantic Ocean. In Barker, P.F., Carlson, R.L., et al., Init. Repts. DSDP, 72: Washington (U.S. Govt. Printing Office), 757-782.

de Klasz, I., 1978. The West African sediments. In Moullade, M., and Nairn, A.E.M. (Eds.),. The Phanerozoic Geology of the World. II. The Mesozoic, A:371-399.

de Klasz, I., and du Chêne, R.J., 1978. Presence of Albian-Cenomanian in Southwestern Nigeria and its paleogeographic implications. $C . R$. Séances SPHN Genève, 13:10-15.

de Klasz, I., Magné, J., and Rérat, D., 1963. Quelques formes nouvelles de Buliminidae caractéristiques du Crétacé supérieur du Gabon (Afrique Équatoriale). Rev. Micropaleontol., 6:145-152.

de Klasz, I., Marie, P., and Meijer, M., 1960. Gabonella nov gen., un nouveau genre de Foraminifères du Crétacé supérieur et du Tertiaire basal de l'Afrique occidentale. Rev. Micropaleontol., 4:77-79.

de Klasz, I., Marie, P., and Rérat, D., 1961. Deux nouvelles espèces du genre Gabonella (Foraminifère) du Crétacé du Gabon (Afrique Équatoriale). Rev. Micropaleontol., 4:77-79. 
de Klasz, I., and Rérat, D., 1962. Quelques nouveaux foraminifères du Crétacé et du Tertiaire du Gabon (Afrique Équatoriale). Rev. Micropaleontol., 4:175-189.

- 1963. The stratigraphic range of the foraminiferal genus Gabonella in the Upper Cretaceous of Gabon (Equatorial Africa). Micropaleontology, 9:325-326.

Eicher, D.L., 1969. Cenomanian and Turonian planktonic foraminifera from the western interior of the United States. In Brönnimann, P., and Renz, H.H. (Eds.). Proc. First Int. Conf. Planktonic Microfossils, 2:163-174.

Eicher, D.L., Frush, M.P., and Moullade, M., 1974. Diversity of Cenomanian benthic foraminifera in Southern Europe. Actes VI, Colloque Africain de Micropaléontologie. Ann. Mines Geol., Tunis, 28:367-388.

Eicher, D.L., and Worstell, P., 1970. Cenomanian and Turonian foraminifera from the Great Plains, United States. Micropaleontology, 16:269-324.

Fayose, E.A., and de Klasz, I., 1976. Microfossils of the Eze-Aku Formation (Turonian) at Nkalagu quarry, eastern Nigeria. Niger. J. Min. Geol., $13: 51-61$

Förster, R., 1978. Evidence for an open seaway between northern and southern proto-Atlantic in Albian times. Nature, 272:158-159.

Fowler, S.P., and Braun, W.K., 1993. Hauterivian to Barremian Foraminifera and Biostratigraphy of the Mount Goodenough Formation, Aklavik Range, Northwestern District of Mackenzie. Bull. Geol. Surv. Can., 443:1-83

Gradstein, F.M., Agterberg, F.P., Ogg, J.G., Hardenbol, J., van Veen, P., Thierry, J., and Huang, Z., 1994. A Mesozoic time scale. J. Geophys. Res., 99:24051-24074

Grzybowski, J., 1898. Otwornice pokladow naftonosnych okolicy Krosna. Rozprawy Wydzialu Matematyczno-Przyrodniczego, Akademia Umiejetnosci $w$ Krakowie, Ser. 2, 33:257-305.

Guérin, S., 1981. Utilisation des foraminifères planctiques et benthiques dans l'étude des paleo-environements océaniques au Crétacé moyen: application au matériel des forages D.S.D.P. de l'Atlantique nord et sud. Comparaison avec la Téthys [Thèse Doctorat]. Univ. Nice.

Haig, D.W., 1982. Early Cretaceous Milioline and Rotaliine Benthic Foraminiferids from Queensland. Palaeontographica A, 177:1-88. , 1992. Aptian-Albian foraminifers from Site 766, Cuvier Abyssal Plain, and comparison with coeval faunas from the Australian region. In Gradstein, F.M., Ludden, J.N., et al., Proc. ODP, Sci. Results, 123: College Station, TX (Ocean Drilling Program), 271-297.

Haig, D.W., and Lynch, D.A., 1993. A late early Albian marine transgressive pulse over northeastern Australia, precursor to epeiric basin anoxia: foraminiferal evidence. Mar. Micropaleontol., 22:311-362.

Holbourn, A.E.L., and Kaminski, M.A., 1995. Valanginian to Barremian benthic foraminifera from ODP Site 766 (Leg 123, Indian Ocean). Micropaleontology, 41:197-250.

- 1997. Lower Cretaceous Benthic Foraminifera of the Indian Ocean. Grzybowski Found. Spec. Publ., 4:1-172.

Jones, J.P., and Parker, W.K., 1860. On the Rhizopodal fauna of the Mediterranean compared with that of the Italian and some other Tertiary deposits. Quart. J. Geol. Soc. London, 16:292-307.

Kaminski, M.A., and Geroch, S., 1993. A revision of foraminiferal species in the Grzybowski Collection. In Kaminski, M.A., Geroch, S., and Kaminski, D.G. (Eds.), The Origins of Applied Micropalaeontology: The School of Józef Grzybowski. Grzybowski Found. Spec. Publ., 1:239-323.

Khan, M.H., 1950. On some new foraminifera from the Lower Gault of southern England. R. Microsc. Soc. London, 70:1-277.

Lambert, G., and Scheibnerová, V., 1974. Albian Foraminifera of Zululand (South Africa) and Great Artesian Basin (Australia). Micropaleontology, 20:76-96.

Leckie, R.M., 1987. Paleoecology of mid-Cretaceous planktonic foraminifera: a comparison of open ocean and epicontinental sea assemblages. Micropaleontology, 33:164-176.

Loeblich, A.R., and Tappan, H., 1992. Present status of foraminiferal classification. In Takayanagi, Y., and Saito, T. (Eds.), Studies in Benthic Foraminifera. Tokai Univ. Press, 93-102.

Loeblich, A.R., Jr., and Tappan, H., 1988. Foraminiferal Genera and Their Classification: New York (Van Nostrand Reinhold).

Magniez-Jannin, F., 1975. Les Foraminifères de l'Albien de l'Aube: Paléontologie, Stratigraphie, Écologie: Paris (Cahiers de Paléontologie).

Malapris, M., 1965. Les Gavelinellidae et formes affinées du gisement Albien de Courcelles (Aube). Rev. Micropaleontol., 8:131-150.

Mascle, J., Lohmann, G.P., Clift, P.D., et al., 1996. Proc. ODP, Init. Repts., 159: College Station, TX (Ocean Drilling Program).
McNeil, D.H., and Caldwell, W.G.E., 1981. Cretaceous rocks and their foraminifera in the Manitoba Escarpment. Spec. Pap. Geol. Assoc. Can., 21:1-439.

Meyn, H., and Vespermann, J., 1994. Taxonomische Revision von Foraminiferen der Unterkreide SE-Niedersachsens nach ROEMER $(1839,1841$, 1842), KOCH (1851) und REUSS (1863). Senckenbergiana Lethaea, 74:49-272.

Moullade, M., 1960. Sur quelques foraminifères du Crétacé inférieur des Baronnies (Drôme). Rev. Micropaleontol., 3:131-142.

1966. Etude stratigraphique et micropaléontologique du Crétacé inférieur de la "Fosse Vocontienne." Doc. Lab. Geol. Fac. Sci. Lyon, 15:1-369.

1974. Zones de Foraminifères de Crétacé inférieur mésogéen. $C$. R. Acad. Sci. Paris, Ser. D, 278:1813-1816.

1984. Intérêt des petits foraminifères benthiques "profonds," pour la biostratigraphie et l'analyse des paléoenvironnements océaniques Mésozoïques. In Oertli, H.J. (Ed.), BENTHOS '83: Proc. 2nd Int. Symp. Benthic Foraminifera. Bull. Cent. Rech. Expl.-Prod. Elf-Aquitaine, 6:429-464.

Moullade, M., and Guérin, S., 1982. Le problème des relations de l'Atlantique Sud et de l'Atlantique Central au Crétacé moyen: nouvelles données microfauniques d'après les forages D.S.D.P. Bull. Soc. Geol. Fr., 24:511-517.

Moullade, M., Mascle, J., Benkhelil, J., Cousin, M., and Tricart, P., 1993. Occurrence of marine mid-cretaceous sediments along the Guinean slope (Equamarge II cruise): their significance for the evolution of the central Atlantic African margin. Mar. Geol., 110:63-72.

Neagu, T., 1975. Monographie de la faune des Foraminifères éocrétacés du couloir de Dimboviciora, de Codlea et des Monts (Persani), (Couches de Carhaga). Mem. Inst. Geol. Geophys., 25:1-141.

Noth, R., 1951. Foraminiferen aus Unter und Oberkreide des österreichischen auteils an flysch, helvetikum und vorland vorkommen. Jahrb. Geol. Bundesanst. Austria, 3:1-91.

Petters, S.W., 1982. Central West African Cretaceous-Tertiary benthic foraminifera and stratigraphy. Palaeontographica A, 179:1-104.

, 1983. Gulf of Guinea planktonic foraminiferal biochronology and geological history of the South Atlantic. J. Foraminiferal Res., 13:32-59.

Reuss, A.E., 1845. Die Versteinerungen der Böhmischen Kreideformation (Vol. 1): Stuttgart (E. Schweizerbart).

1863. Die Foraminiferen des norddeutschen Hils und Gault. Sitzungsber. Kais. Akad. Wiss. Wien Math.-Naturwiss. Kl., 46:5-100.

Revets, S.A., 1996. The generic revision of five families of Rotaliine foraminifera. Spec. Publ. Cushman Found. Foraminiferal Res., 34:1-108.

Riegraf, W., and Luterbacher, H., 1989. Benthonische Foraminiferen aus der Unterkreide des "Deep Sea Drilling Project” (Leg 1-79). Geol. Rundsch., 78:1063-1120.

Robaszynski, F., and Caron, M., 1995. Foraminifères planctoniques du Crétacé: commentaire de la zonation Europe-Méditerranée. Bull. Soc. Geol. Fr., 166:681-692.

Roemer, F.A., 1838. Die Cephalopoden des norddeutschen tertiaeren Meeressandes. Neues Jahrb. Miner., 381-394. -1841. Die Versteinerungen des Norddeutschen Kreidegebirges: Hannover (Hahn).

Saint-Marc P., and N'Da, V., in press. Biostratigraphie et paléoenvironnements des dépôts crétacés au large d'Abidjan (Golfe de Guinée). Cretaceous Res.

Schacko, G., 1897. Beitrag über Foraminiferen aus dem Cenoman-Kreide von Moltzow in Mecklenburg. Archiv Vereins Freunde Naturgesch. Mecklenberg (1896), 50:161-168.

Scheibnerová, V., 1976. Cretaceous Foraminifera of the Great Australian Basin. New South Wales Geol. Surv. Mem. Palaeontol., 17:1-265.

1978. Aptian and Albian benthic foraminifers of Leg 40, sites 363 and 364, southern Atlantic. In Bolli, H.M., Ryan, W.B.F., et al., Init. Repts. DSDP, 40: Washington (U.S. Govt. Printing Office), 741-757.

Stelck, C.R., and Wall, J.H., 1954. Kaskapau Foraminifera from Peace River area of western Canada. Res. Counc. Alberta Rep., 68:1-38.

Tappan, H., 1940. Foraminifera from the Grayson Formation of northern Texas. J. Paleontol., 17:93-126.

Thurow, J., 1988. Cretaceous radiolarians of the North Atlantic Ocean: ODP Leg 103 (Sites 638, 640, and 641) and DSDP Legs 93 (Site 603) and 47B (Site 398). In Boillot, G., Winterer, E.L., et al., Proc. ODP, Sci. Results, 103: College Station, TX (Ocean Drilling Program), 379-418.

Thurow, J., and Kuhnt, W., 1986. Mid-Cretaceous of the Gibraltar Arch Area. In Summerhayes, C.P., and Shackleton, N.J. (Eds.), North Atlantic Palaeoceanography. Geol. Soc. Spec. Publ., 22:423-445. 
Tronchetti, G., and Grosheny, D., 1991. Les assemblages de foraminifères benthiques au passage Cénomanien-Turonien à Vergons, S-E France. Geobios, 24:13-31.

Walker, G., and Jacob, E., 1798. In Adams, G. (Ed.), Essays on the Microscope (2nd ed.): London (Dillon and Keating).

Weidich, K.F., 1990. Die kalkalpine Unterkreide und ihre Foraminiferenfauna. Zitteliana,17, Abhandl. Bayerisch. Staatssam. Palaeontol. Hist. Geol.

Wiedmann, J., and Neugebauer, J., 1978. Lower Cretaceous ammonites from the South Atlantic Leg 40 (DSDP), their stratigraphic value and sedimen- tologic properties. In Bolli, H.M., Ryan, W.B.F., et al., Init. Repts. DSDP, 40: Washington (U.S. Govt. Printing Office), 709-734.

Date of initial receipt: 23 September 1996

Date of acceptance: 30 April 1997

Ms 159SR-033 

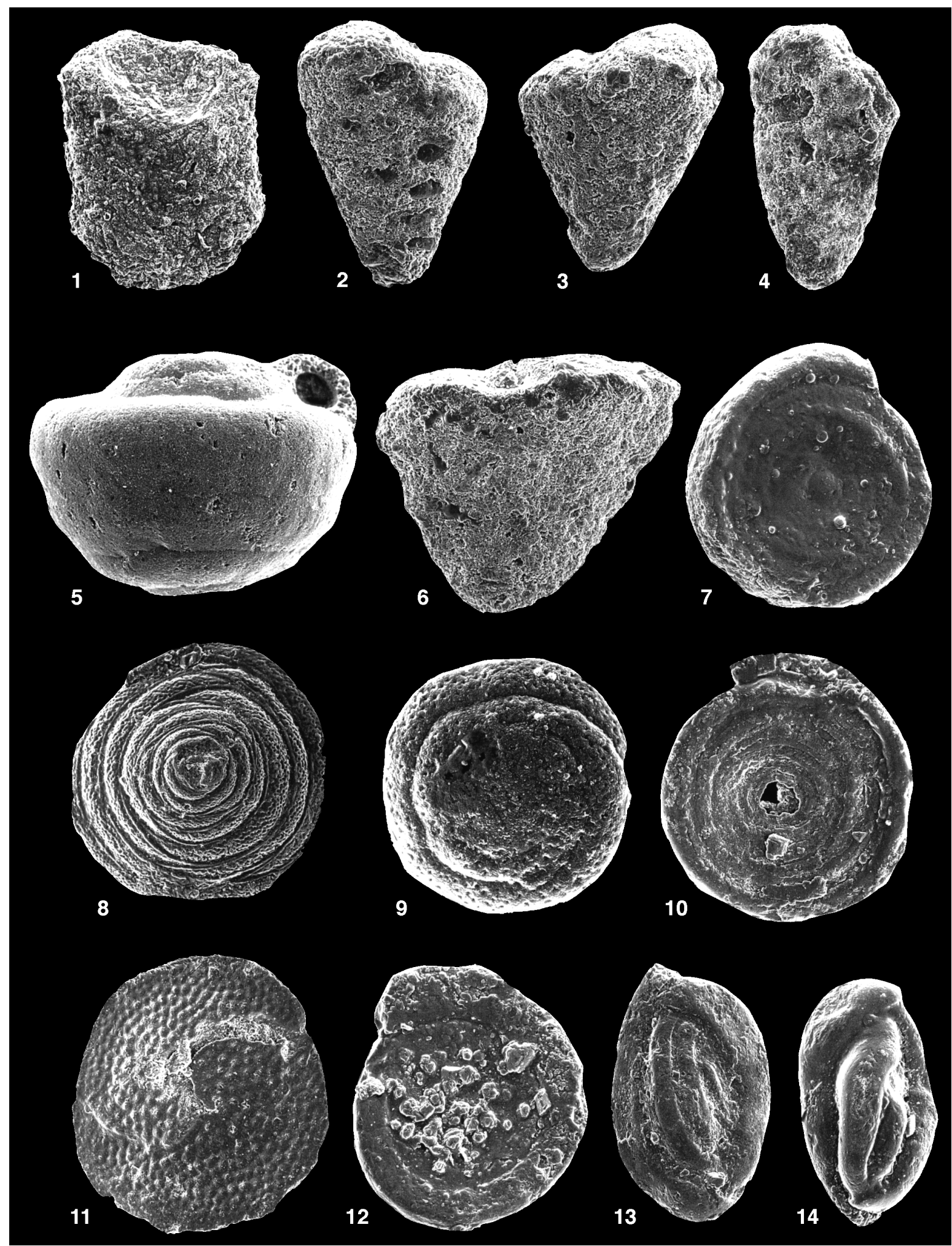

Plate 1. 1. Nothia latissima (Grzybowski), 72×; Sample 159-962D-20R-3, 56-60 cm. 2. ?Spiroplectinella sp. 1, 183×; Sample 159-962D-30R-1, 93-97 cm. 3. ?Spiroplectinella sp. 1, 183×; Sample 159-962D-30R-2, 52-55 cm. 4. ?Spiroplectinella sp. 1; 165×, Sample 159-962D-37R-2, 143-146 cm. 5. Glomospira charoides (Jones \& Parker), 183×; Sample 159-962B-8H-CC, 1-4 cm. 6. ?Spiroplectinella sp.1, 165×; Sample 159-962D-28R-1, 92-96 cm. 7. Spirillina minima Schacko, 190×; Sample 159-962D-37R-CC. 8. Patellina subcretacea Cushman \& Alexander, 200×; Sample 159-962D-20R-4, 44-49 cm. 9. Trocholina infragranulata Noth, 240×; Sample 159-962D-20R-4, 119-122 cm. 10. Spirillina minima Schacko, 195×; Sample 159-962D-20R-4, 44-49 cm. 11. Patellina subcretacea Cushman \& Alexander, 140×; Sample 159-962D-20R-4, 44-49 cm. 12. Trocholina infragranulata Noth, 240×; Sample 159-962D-28R-1, 92-96 cm. 13. Quinqueloculina sp., 130x; Sample 159-962D-24R-3, 13-17 cm. 14. Quinqueloculina sp., 130×; Sample 159-962D-20R-4, 44-49 cm. 


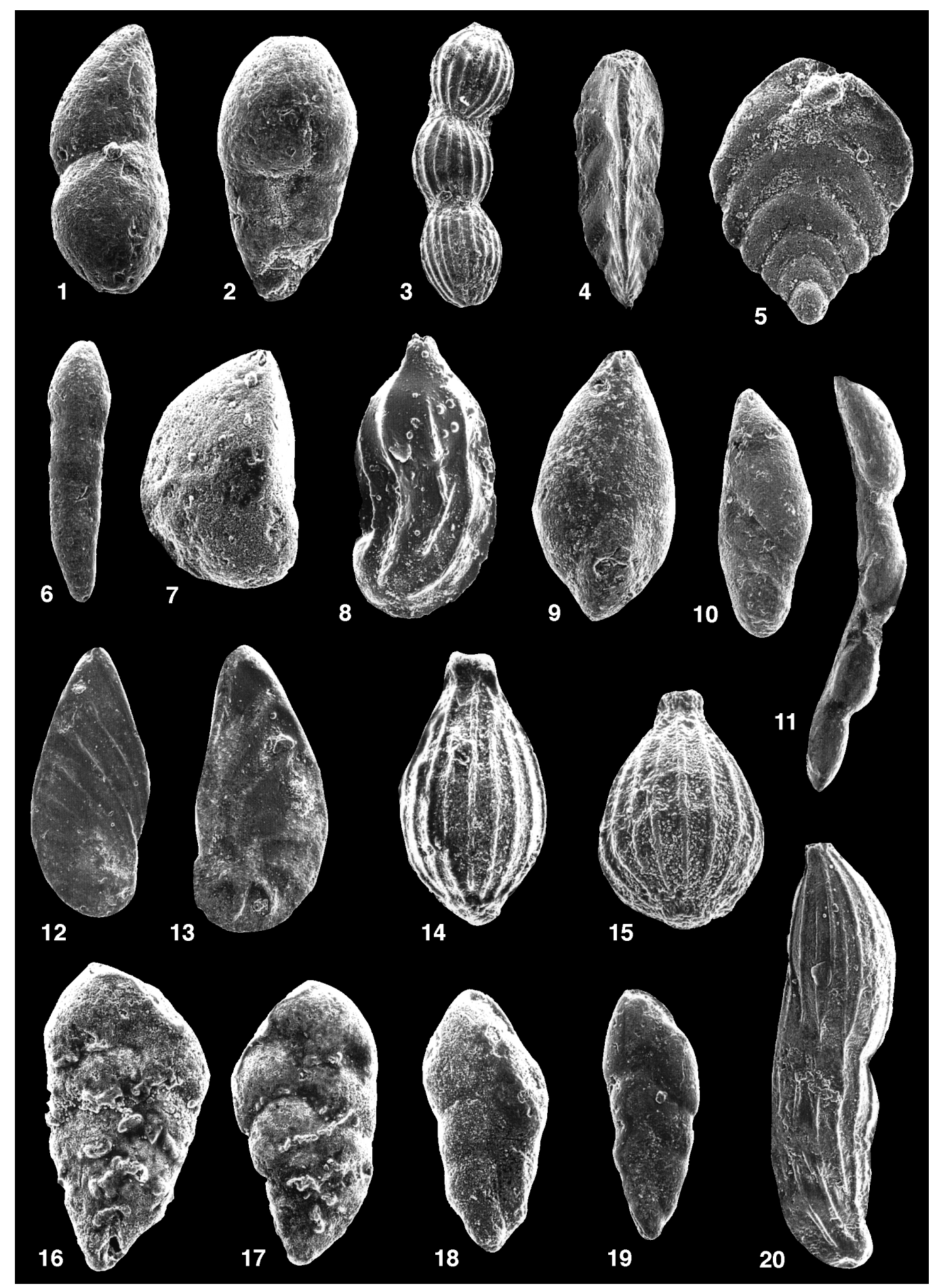

Plate 2. 1. Laevidentalina oligostegia (Reuss), 165×; Sample 159-962D-34R-1, 118-122 cm. 2. Pseudonodosaria sp. 1, 240×; Sample 159-962D-35R-3, 87-91 cm. 3. Pyramidulina sceptrum (Reuss), 110X; Sample 159-962D-20R-4, 44-49 cm. 4. Tristix acutangula (Reuss), 110×; Sample 159-962D-30R-1, 93-97 cm. 5. Frondicularia lamellata Tappan, 130X; Sample 159-962D-12R-2, 11-14 cm. 6. Lingulonodosaria nodosaria (Reuss), 130X; Sample 159-962D-36R-1, 48$51 \mathrm{~cm}$. 7. Lenticulina sp., 165×; Sample 159-962D-24R-1, 34-38 cm. 8. Marginulinopsis jonesi (Reuss), 130×; Sample 159-959D-71R-1, 30-33 cm. 9. Globulina prisca (Reuss), 195×; Sample 159-962D-20R-4, 44-49 cm. 10. Astacolus calliopsis (Reuss), 100×; Sample 159-962D-28R-1, 92-96 cm. 11. Laevidentalina debilis (Berthelin), 80×; Sample 159-962D-24R-2, 141-145 cm. 12. Planularia complanata (Reuss), 80×; Sample 159-962D-28R-1, 92-96 cm. 13. Planularia complanata (Reuss), 140×; Sample 159-962D-28R-2, 67-70 cm. 14. Oolina sulcata (Walker \& Jacob), 195×; Sample 159-962D-37R-2, 143-146 cm. 15. Oolina sulcata (Walker \& Jacob), 195X; Sample 159-962D-28R-1, 92-96 cm. 16. Bolivina anambra Petters, 270×; Sample 159-962D-9R-1, 34-38 cm. 17. Bolivina anambra Petters, 195X; Sample 159-962D-9R-1, 34-38 cm. 18. Bolivina sp. 1, 145×; Sample 159-962D-18R-4, 32-36 cm. 19. Bolivina sp. 1, 140×; Sample 159-962D-20R-4, 44-49 cm. 20. Marginulinopsis striatocostata (Reuss), 110×; Sample 159-962D-24R-3, 13-17 cm. 


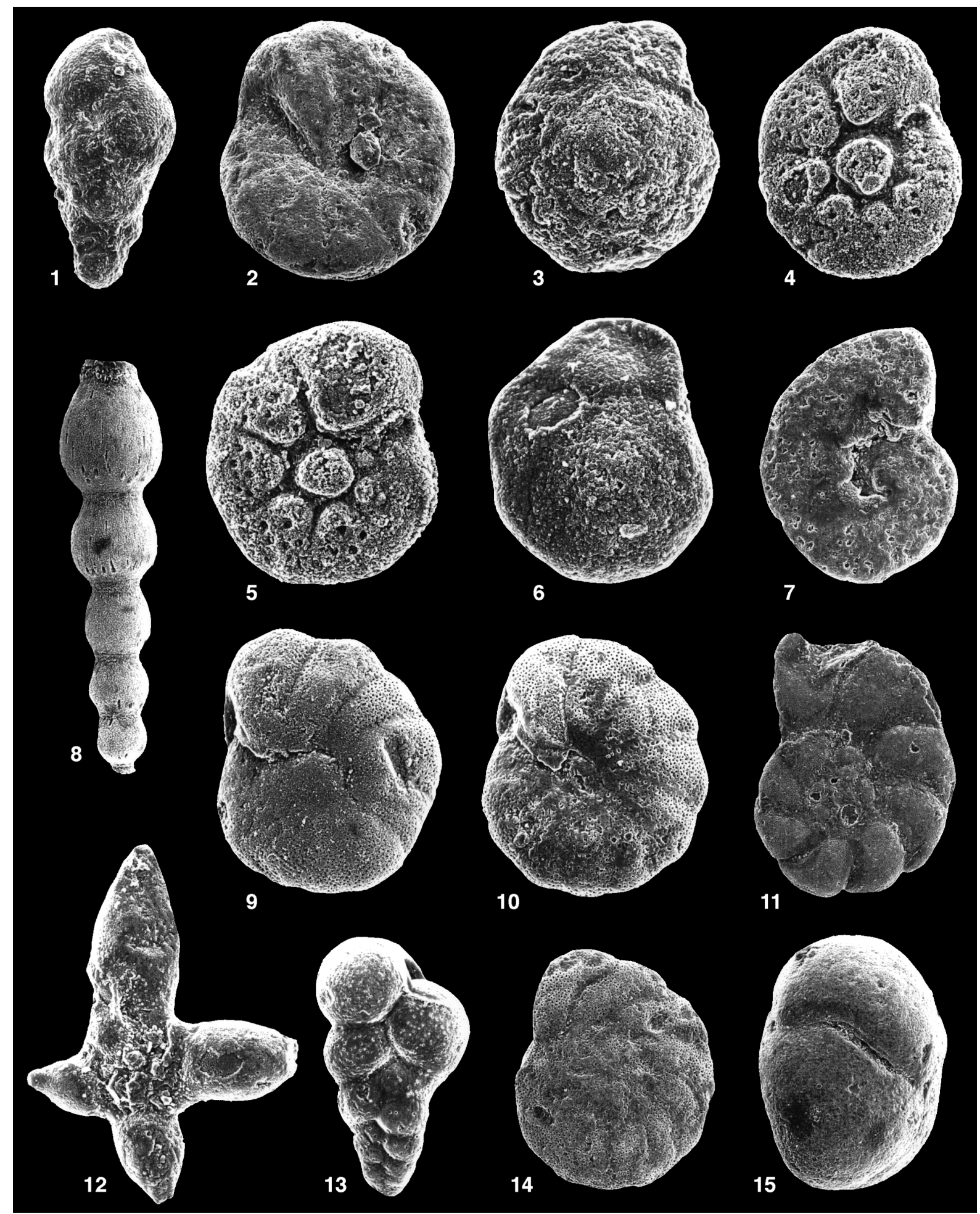

Plate 3. 1. Neobulimina albertensis (Stelck \& Wall), 180×; Sample 159-962D-34R-3, 11-14 cm. 2. Osangularia sp. 1, 275×; Sample 159-962D-37R-2, 143$146 \mathrm{~cm}$. 3. Osangularia sp. 1, 250×; Sample 159-962D-20R-3, 56-60 cm. 4. Osangularia sp. 2, 275×; Sample 159-962D-18R-3, 10-15 cm. 5. Osangularia sp. 2, 290×; Sample 159-962D-16R-3, 73-76 cm. 6. Osangularia sp. 2, 310×; Sample 159-962D-20R-4, 119-122 cm. 7. Gavelinella sp., 290×; Sample 159-962D18R-4, 32-36 cm. 8. Stilostomella sp., 265×; Sample 159-962B-8H-5, bottom. 9. Berthelina intermedia (Berthelin), 180×; Sample 159-962D-24R-2, 71-75 cm. 10. Berthelina intermedia (Berthelin), 180X; Sample 159-962D-16R-1, 9-12 cm. 11. Gavelinella sp., 130X; Sample 159-962D-20R-4, 44-49 cm. 12. Schackoina sp., 265×; Sample 159-962D-23R-CC, 11-15 cm. 13. Heterohelix sp., 175×; Sample 159-962D-9R-1, 34-38 cm. 14. Berthelina intermedia (Berthelin). 130×; Sample 159-962D-19R-2, 22-25 cm. 15. Gyroidinoides cf. nitidus (Reuss), 110×; Sample 159-962D-36R-3, 98-101 cm. 